\title{
A tumor-targeted trimeric 4-1BB-agonistic antibody induces potent anti-tumor immunity without systemic toxicity
}

\author{
Marta Compte ${ }^{1}$, Seandean Lykke Harwood ${ }^{2}$, Ines G. Muñoz ${ }^{3}$, Rocio Navarro ${ }^{4}$, Manuela Zonca ${ }^{1}$, \\ Gema Perez-Chacon 5,6, Ainhoa Erce-Llamazares, Nekane Merino (10 7, Antonio Tapia-Galisteo ${ }^{4}$, \\ Angel M. Cuesta ${ }^{4}$, Kasper Mikkelsen ${ }^{2}$, Eduardo Caleiras $^{8}$, Natalia Nuñez-Prado ${ }^{4}$, M. Angela Aznar ${ }^{9}$, \\ Simon Lykkemark2 ${ }^{2}$, Jorge Martínez-Torrecuadrada ${ }^{3}$, Ignacio Melero9,10,11,12, Francisco J. Blanco (1) 7,13, \\ Jorge Bernardino de la Serna (10) ${ }^{14,15}$, Juan M. Zapata ${ }^{5,6}$, Laura Sanz (iD ${ }^{4}$ \& Luis Alvarez-Vallina 2,16,17
}

The costimulation of immune cells using first-generation anti-4-1BB monoclonal antibodies (mAbs) has demonstrated anti-tumor activity in human trials. Further clinical development, however, is restricted by significant off-tumor toxicities associated with $\mathrm{Fc \gamma R}$ interactions. Here, we have designed an Fc-free tumor-targeted 4-1BB-agonistic trimerbody, 1D8 ${ }^{\mathrm{N}} / \mathrm{C}_{\mathrm{EGa1}}$, consisting of three anti-4-1BB single-chain variable fragments and three anti-EGFR singledomain antibodies positioned in an extended hexagonal conformation around the collagen XVIII homotrimerization domain. The1D8 ${ }^{\mathrm{N} / \mathrm{C}} \mathrm{EGa1}$ trimerbody demonstrated high-avidity binding to 4-1BB and EGFR and a potent in vitro costimulatory capacity in the presence of EGFR. The trimerbody rapidly accumulates in EGFR-positive tumors and exhibits anti-tumor activity similar to IgG-based 4-1BB-agonistic mAbs. Importantly, treatment with $1 \mathrm{D} 88^{\mathrm{N} / \mathrm{C}_{\mathrm{EG}} \text { 1 }}$ does not induce systemic inflammatory cytokine production or hepatotoxicity associated with IgG-based 4-1BB agonists. These results implicate FcyR interactions in the 4-1BB-agonistassociated immune abnormalities, and promote the use of the non-canonical antibody presented in this work for safe and effective costimulatory strategies in cancer immunotherapy.

\footnotetext{
${ }^{1}$ Department of Antibody Engineering, Leadartis SL, 28008 Madrid, Spain. ${ }^{2}$ Immunotherapy and Cell Engineering Laboratory, Department of Engineering, Aarhus University, 8000 C Aarhus, Denmark. ${ }^{3}$ Crystallography and Protein Engineering Unit, Spanish National Cancer Research Centre (CNIO), 28029 Madrid, Spain. ${ }^{4}$ Molecular Immunology Unit, Hospital Universitario Puerta de Hierro Majadahonda, 28222 Majadahonda, Madrid, Spain. ${ }^{5}$ Instituto de Investigaciones Biomédicas Alberto Sols (IIBm), CSIC-UAM, 28029 Madrid, Spain. ${ }^{6}$ Instituto de Investigación Sanitaria La Paz (IdiPaz), 28029 Madrid, Spain. ${ }^{7}$ Structural Biology Unit, CIC bioGUNE, Parque Tecnológico de Bizkaia, 48160 Derio, Spain. ${ }^{8}$ Histopathology Unit, Spanish National Cancer Research Centre (CNIO), 28029 Madrid, Spain. ${ }^{9}$ Department of Immunology and Immunotherapy, Center for Applied Medical Research (CIMA), University of Navarra, 31008 Pamplona, Spain. ${ }^{10}$ Department of Immunology, University Clinic, University of Navarra, 31008 Pamplona, Spain. ${ }^{11}$ Instituto de Investigación Sanitaria de Navarra (IdISNA), 31008 Pamplona, Spain. ${ }^{12}$ CIBERONC-Centro virtual de Investigación Biomédica en red de Oncología, 28029 Madrid, Spain. ${ }^{13}$ IKERBASQUE, Basque Foundation for Science, 48013 Bilbao, Spain. ${ }^{14}$ Central Laser Facility, Science and Technology Facilities Council, Rutherford Appleton Laboratory, Research Complex at Harwell, OX11 OQX Harwell-Oxford, UK. ${ }^{15}$ Department of Physics, King's College London, WC2R 2LS London, UK.

${ }^{16}$ Cancer Immunotherapy Unit (UNICA), Department of Immunology, Hospital Universitario 12 de Octubre, 28041 Madrid, Spain. ${ }^{17}$ Immuno-Oncology and Immunotherapy Group, Instituto de Investigación Sanitaria 12 de Octubre (i+12), 28041 Madrid, Spain. Correspondence and requests for materials should be addressed to L.A.-V. (email: lav@eng.au.dk)
} 
M odulating immune responses using monoclonal antibodies (mAbs) is a promising approach to cancer therapy. Antagonistic mAbs directed against checkpoint inhibitors such as cytotoxic T-lymphocyte-associated antigen 4 and programmed cell death 1 /programmed cell death ligand 1 (PD-L1) have been clinically approved, and agonistic mAbs targeting costimulatory receptors are undergoing clinical trials ${ }^{1}$. Costimulatory receptors of the tumor necrosis factor (TNF) receptor superfamily (TNFRSF), such as CD40, OX40, and 4-1BB, are particularly interesting targets, as these receptors are not constitutively expressed on resting naive $\mathrm{T}$ cells but acquired upon activation ${ }^{2-4}$. This limits the potential deleterious side effects of the treatment ${ }^{5}$.

4-1BB (CD137, TNFRSF9) has only one confirmed ligand [4-1BB-Ligand (4-1BBL), TNFSF9], which is expressed on macrophages, activated $B$ cells, and dendritic cells ${ }^{6}$. Engagement of $4-1 B B$ by its ligand or an agonistic antibody promotes $\mathrm{T}$ cell proliferation, cytokine production, and cytolytic effector functions and protects lymphocytes from programmed cell death ${ }^{7,8}$. Furthermore, engagement of $4-1 \mathrm{BB}$ on natural killer cells enhances cytokine release (including interferon (IFN)- $\gamma)^{9}$ and antibody-dependent cellular cytotoxicity ${ }^{10,11}$. Indeed, treatment of mice with 4-1BB-agonistic mAbs was found to induce tumor regression of established and poorly immunogenic tumors as early as $1997^{12}$. Since then, a large body of accumulated preclinical data has been gathered that supports the induction of 4$1 \mathrm{BB}$ signaling in cancer immunotherapy, both as a single agent and in combination therapies ${ }^{13}$.

The effect of 4-1BB-agonistic mAbs is not spatially restricted to the tumor, and peripheral toxicities can therefore reduce the therapeutic window for 4-1BB-targeting therapies. In mice, 4-1BB $\mathrm{mAbs}$ have been shown to cause immune anomalies, notably polyclonal activation of $\mathrm{CD}^{+} \mathrm{T}$ cells and secretion of inflammatory cytokines, which affected the function of liver, spleen, and bone marrow ${ }^{14,15}$. In clinical studies, an anti-4-1BB mAb (BMS663513, urelumab) showed tolerable side effects in an initial Phase I trial, but a follow-up Phase II trial revealed severe liver toxicity in $\approx 10 \%$ of the patients that resulted in two fatalities ${ }^{16}$. As a consequence, trials with urelumab were terminated ${ }^{17}$. Recently, data were presented on a dose-escalation study with urelumab as monotherapy and in combination with nivolumab ${ }^{18}$. The reduced dose ameliorated liver toxicity; however, the clinical activity of urelumab at the tolerated dose was limited. An integrated safety analysis of patients treated with urelumab confirmed a clear association between transaminitis and urelumab dose $\mathrm{e}^{19}$. Utomilumab is another anti-41BB mAb in clinical trials with a better safety profile than urelumab but is a relatively less potent $4-1 \mathrm{BB}$ agonist $^{20}$.

As it stands, costimulation by $4-1 \mathrm{BB}$-agonistic mAbs is an otherwise viable therapeutic approach held back by off-tumor toxicities and could therefore benefit greatly from the addition of tumor-targeting functionality to restrict its effect to the tumor deposits. Furthermore, if this is conveyed by binding domains specific to cell surface tumor-associated antigens (TAAs), the anti-4-1BB antibodies will then cluster on the surface of cancer cells. This may allow the antibodies to mimic physiological 4$1 \mathrm{BBL}$ and could have a major impact on the induction of $4-1 \mathrm{BB}$ signaling. Importantly, $4-1 \mathrm{BBL}$ is a trimeric membrane protein and can be proteolytically processed into soluble trimeric ligands with a significantly reduced signaling activity compared to their transmembrane counterparts ${ }^{21}$. Signaling can be restored by higher-order oligomerization ${ }^{21,22}$, cell surface display of anti-4$1 \mathrm{BB}$ single chain antibody fragments ( $\mathrm{scFv}$ ) expressed by tumor cells in fusion with membrane proteins ${ }^{23,24}$, or antibodymediated display by fusing the extracellular domain of $4-1 \mathrm{BBL}$ to a TAA-specific $\mathrm{scFv}^{25}$. Another strategy is the use of anti-4-
$1 \mathrm{BB}$ oligonucleotide aptamers instead of $4-1 \mathrm{BBL}^{26,27}$. In animal models, systemic delivery of a 4-1BB-agonistic aptamer conjugated to a prostate-specific membrane antigen aptamer led to superior therapeutic effect compared to immunoglobulin $G$ (IgG)-based 4-1BB-agonistic antibodies ${ }^{26}$. It has also been recently reported that anchoring anti-4-1BB $\mathrm{F}\left(\mathrm{ab}^{\prime}\right)_{2}$ fragments and interleukin (IL)-2 on the surface of liposomes induced effective antitumor immunity without systemic toxicity ${ }^{28}$.

In this article, we describe the adaptation of the first-generation 4-1BB agonistic IgG $1 \mathrm{D} 8$ to a recombinant antibody format, the trimerbody. This format is based on the fusion of antibodyderived binding domains to the small homotrimerization region from murine collagen XVIII, which yields trimeric antibodies $^{29-31}$. Trimerbodies have two major advantages compared to the IgG mAb: they lack the fragment crystallizable ( $\mathrm{Fc}$ ) region involved in $4-1 \mathrm{BB}$-mediated toxicity ${ }^{20}$; and they are trimeric, as is physiological 4-1BBL. We generated a panel of 1D8 scFv-based N-terminal trimerbodies $\left(1 \mathrm{D} 8^{\mathrm{N}}\right)$ using linkers of different lengths and identified $1 \mathrm{D} 8{ }^{\mathrm{N} 18}$, the trimerbody with the longest linker, as showing the most potent costimulatory activity. $1 \mathrm{D} 8^{\mathrm{N} 18}$ was therefore used as the basis for a bispecific tumortargeted trimerbody, $1 \mathrm{D} 8^{\mathrm{N} / \mathrm{C}} \mathrm{EGa} 1$, by adding the epidermal growth factor receptor (EGFR)-binding EGal single-domain antibody ${ }^{32}$. Compared to both $1 \mathrm{D} 8 \mathrm{IgG}$ and $1 \mathrm{D} 8^{\mathrm{N} 18}, 1 \mathrm{D} 8^{\mathrm{N} /}$ $\mathrm{C}_{\mathrm{EGal}}$ was a more potent costimulator in vitro and showed enhanced tumor homing and tumor inhibition in vivo, with no indication of the $4-1 \mathrm{BB} \mathrm{mAb}$-associated toxicity.

\section{Results}

Design of 4-1BB-agonistic trimerbodies. Using the $\mathrm{scFv}$ derived from the rat $\operatorname{IgG}_{2 \mathrm{a}}$, anti-4-1BB $1 \mathrm{D} 8 \mathrm{mAb}^{33}$ (Fig. 1a), we designed a panel of $1 \mathrm{D} 8 \mathrm{scFv}$-based $\mathrm{N}$-terminal trimerbodies $\left(1 \mathrm{D} 8{ }^{\mathrm{N}}\right)$. Three candidates were generated with varied lengths of the flexible linker connecting the $1 \mathrm{D} 8 \mathrm{scFv}$ to a murine collagen XVIIIderived homotrimerization (TIE ${ }^{\mathrm{XVIII}}$ ) domain: $1 \mathrm{D} 8^{\mathrm{NO}}$ has no linker, while $1 \mathrm{D} 8^{\mathrm{N} 5}$ and $1 \mathrm{D} 8^{\mathrm{N} 18}$ have 5 - and 18-residue-long linkers, respectively (Fig. 1b). All three constructs were expressed by transfected HEK293 cells at similar levels to MFE- $23^{\mathrm{N} 18}$, a benchmark N-terminal trimerbody based on the anti-CEA MFE$23 \mathrm{scFv}^{29}$. In western blot analysis under reducing conditions, the $1 \mathrm{D} 8{ }^{\mathrm{N}}$ trimerbodies were single-chain-type molecules with a migration pattern consistent with the molecular weights calculated from their amino acid sequences $(34.4,34.7$, and $36.8 \mathrm{kDa}$, in the order of increasing linker length) (Supplementary Figure 1a). Additionally, they specifically recognized murine 4-1BB in fusion with human Fc (m4-1BB) immobilized on plastic, as determined by enzyme-linked immunosorbent assay (ELISA; Supplementary Figure 1b).

The three 4-1BB-specific trimerbodies were produced in stably transfected HEK293 cells and purified by immobilized metal affinity chromatography, with a yield of roughly $1 \mathrm{mg} / \mathrm{l}$ of conditioned medium (Supplementary Figure 2a). Their binding kinetics were then studied using biolayer interferometry (BLI). While all 1D8 antibodies showed low picomolar-range $K_{\mathrm{D}}$ toward $\mathrm{m} 4-1 \mathrm{BB}$ immobilized on biosensors, the $1 \mathrm{D} 8^{\mathrm{N}}$ trimerbodies were found to dissociate at approximately half the rate of the parental $1 \mathrm{D} 8 \mathrm{mAb}$ (Fig. 2a, Supplementary Table 1). This indicates that the $1 \mathrm{D} 88^{\mathrm{N}}$ trimerbodies are in fact functionally trivalent and therefore have a higher functional affinity than the bivalent 1D8 IgG. Furthermore, $1 \mathrm{D} 8^{\mathrm{N} 18}, 1 \mathrm{D} 8^{\mathrm{N} 5}$, and $1 \mathrm{D} 8^{\mathrm{N} 0}$ showed extremely similar kinetic rate constants, indicating that none of the linker length variations structurally compromise the $1 \mathrm{D} 8 \mathrm{scFv}$ or sterically hinder its access to antigen. The ability of $1 \mathrm{D} 8^{\mathrm{N}}$ trimerbodies to detect $\mathrm{m} 4-1 \mathrm{BB}$ in a cellular context was studied by flow cytometry. All 1D8 ${ }^{\mathrm{N}}$ trimerbodies bound to HEK293 cells 


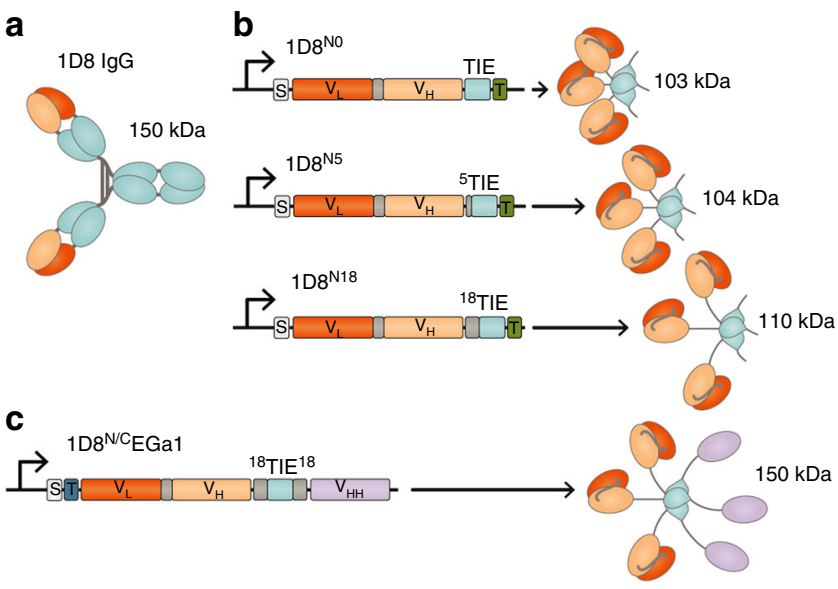

Fig. 1 Schematic diagrams of 4-1BB-agonistic trimerbodies. Protein structure of the anti-4-1BB $\operatorname{lgG}$ (a) and the gene layout (left) and protein structure (right) of monospecific (b) and bispecific trimerbodies (c). The variable regions derived from 1D8 antibody are represented in orange, the anti-EGFR $\mathrm{V}_{\mathrm{HH}}$ EGa1 in violet, the structural domains in light blue, and the linker regions in gray. The 1D8 scFv-based $\mathrm{N}$-terminal trimerbodies' (1D8 ${ }^{\mathrm{N}}$ ) gene constructs (b) contain a signal peptide from oncostatin $M$ (white box) and the 1D8 scFv gene $\left(V_{L}-V_{H}\right)$ connected directly or through flexible linkers to the mouse TIEXVIII domain. In the bispecific 1D8 ${ }^{\mathrm{N}} / \mathrm{C}_{\mathrm{EG}}$ 1 trimerbody (c), the anti-human EGFR $\mathrm{V}_{\mathrm{HH}}$ EGa1 is fused to the C-terminus of $1 \mathrm{D} 8^{\mathrm{N} 18}$ through a flexible linker. Arrows indicate the direction of transcription. His6-myc tag (green box) and FLAG-strep tags (dark blue box) were appended for immunodetection

transfected to express murine $4-1 \mathrm{BB}$ on their cell surface (HEK293 ${ }^{\text {4-1BB }}$ ) but not to untransfected HEK293 cells (Supplementary Figure $2 \mathrm{~b})$. The binding of $1 \mathrm{D} 8^{\mathrm{N} 0}$ to HEK293 ${ }^{\mathrm{m} 4-1 \mathrm{BB}}$ cells was less efficient than that of the $1 \mathrm{D} 8^{\mathrm{N} 5}$ and $1 \mathrm{D} 8^{\mathrm{N} 18}$ (Supplementary Figure 2b). $1 \mathrm{D} 8^{\mathrm{N} 5}, 1 \mathrm{D} 8^{\mathrm{N} 18}$, and $1 \mathrm{D} 8 \mathrm{IgG}$ all bound to activated mouse $\mathrm{CD} 8 \mathrm{a}^{+} \mathrm{T}$ cells but did not bind the unstimulated T cells (Fig. 2b). The binding of $1 \mathrm{D} 8^{\mathrm{N} 5}$ and $1 \mathrm{D} 8^{\mathrm{N} 18}$ was competitively inhibited by $1 \mathrm{D} 8$ IgG (Supplementary Figure $2 \mathrm{c}$ ). These results show that the $1 \mathrm{D} 8^{\mathrm{N}}$ trimerbodies retain the ability to bind to endogenous murine $4-1 \mathrm{BB}$.

We proceeded to investigate the costimulatory capability of the $1 \mathrm{D} 8{ }^{\mathrm{N}}$ trimerbodies by testing their effect on the proliferation, IFN$\gamma$ secretion, and viability of mouse CD8a ${ }^{+} \mathrm{T}$ cells in the presence of a suboptimal dose of anti-CD3 mAb. $1 \mathrm{D} 8 \mathrm{IgG}$ and $1 \mathrm{D} 8^{\mathrm{N} 18}$ increased proliferation ( $P=0.0163$ and $P=0.0013$, respectively) and IFN- $\gamma$ secretion $(P=0.0092$ and $P=0.0101$, respectively) similarly to each other (Fig. $2 c, d$ ), and $1 \mathrm{D} 88^{\mathrm{N} 18}$ was significantly more potent than $1 \mathrm{D} 8^{\mathrm{N} 5}$ and $1 \mathrm{D} 8^{\mathrm{N} 0}(P=0.0234$ and $P=0.0016$, respectively; Fig. 2c). After 72 h, a statistically significant increased viability of $\mathrm{CD} 8 \mathrm{a}^{+} \mathrm{T}$ cells stimulated with $1 \mathrm{D} 8 \mathrm{IgG}$ and $1 \mathrm{D} 8^{\mathrm{N} 18}$ was observed ( $P=0.005$ and $P=0.015$, respectively; Fig. 2e). Furthermore, $1 \mathrm{D} 88^{\mathrm{N} 18}$ was significantly more potent than $1 \mathrm{D} 8 \mathrm{IgG}$ $(P=0.046$; Fig. 2e). The recombinant soluble mouse 4-1BBL (m41BBL) was essentially inactive (Fig. 2c, e). The m4-1BBL migrates at approximately $40 \mathrm{kDa}$ in reducing conditions and at approximately $70 \mathrm{kDa}$ in non-reducing conditions, compatible with a trimer (Supplementary Figure 3a). The binding to m4-1BB expressed on the cell surface was less efficient than the $1 \mathrm{D} 8^{\mathrm{N} 18}$ (Supplementary Figure $3 \mathrm{~b}$ ), and competition ELISA demonstrated that $\mathrm{m} 4-1 \mathrm{BBL}$ and $1 \mathrm{D} 88^{\mathrm{N} 18}$ recognize different regions of the $\mathrm{m} 4$ 1BB (Supplementary Figure 3c). Next, we investigated the spatiotemporal distribution and dynamics of the interactions between cell surface m4-1BB and CF488A-labeled m4-1BBL, 1D8 IgG or $1 \mathrm{D} 8^{\mathrm{N} 18}$ (Supplementary Figure 4) in living HEK293 ${ }^{\mathrm{m} 4-1 \mathrm{BB}-\mathrm{S}}$ cells displaying homogenous expression of the receptor (Supplementary
Figure 5). Employing raster imaging correlation spectroscopy $(\text { RICS })^{34}$, we observed and quantified receptor clustering and its molecular mobility upon binding. We observed that m4-1BBL does not induce receptor clustering but rather internalization of the receptor into the cytoplasm $\left(\approx 70 \mu \mathrm{m}^{2} / \mathrm{s}\right)$ (Supplementary Figure $6 a)$. In contrast, both $1 \mathrm{D} 8 \mathrm{IgG}$ and $1 \mathrm{D} 8^{\mathrm{N} 18}$ induce cluster formation, reducing the lateral mobility drastically at the plasma membrane upon binding, from $\approx 1.5$ to 0.35 and from $\approx 1.0$ to 0.15 $\mu \mathrm{m}^{2} / \mathrm{s}$, respectively (Fig. 2f and Supplementary Figure $6 \mathrm{~b}, \mathrm{c}$ ). $1 \mathrm{D} 8{ }^{\mathrm{N} 18}$ formed larger and more numerous membrane clusters, which consequently impeded the lateral diffusion to a greater degree, which indicates more effective and extensive crosslinking (Fig. 2g).

As the $1 \mathrm{D} 88^{\mathrm{N} 18}$ demonstrated improved $\mathrm{T}$ cell costimulatory activity and induced receptor clustering to a greater degree, we chose this particular configuration for subsequent studies. We used size exclusion chromatography with multi-angle light scattering (SEC-MALS) to investigate the oligomeric state of $1 \mathrm{D} 8{ }^{\mathrm{N} 18}$. It eluted as a major symmetric peak with a mass of 112 $\mathrm{kDa}$ (Supplementary Figure $7 \mathrm{a}$ ), close to the predicted $110.1 \mathrm{kDa}$ of $1 \mathrm{D} 8^{\mathrm{N} 18}$ without signal sequence (mass spectrometry by matrix assisted laser desorption/ionization (MALDI) confirmed its absence). Two minor peaks were also detected, the smallest being a protein impurity, as seen by sodium dodecyl sulfatepolyacrylamide gel electrophoresis (SDS-PAGE; Supplementary Figure $7 \mathrm{~b}$ ). The other peak migrates in SDS-PAGE as $1 \mathrm{D} 8 \mathrm{~N}^{\mathrm{N} 18}$ but has a native mass of $244 \mathrm{kDa}$, probably corresponding to trimer-dimers. The two species can be separated by SEC, but reinjection of the major peak gives another minor trimer-dimer peak (Supplementary Figure 7c), indicating an equilibrium where the trimeric species are predominant $(85 \%$ and $97 \%$ at 1.0 and $0.26 \mathrm{~g} / \mathrm{l}$, respectively). The circular dichroism spectrum of $1 \mathrm{D} 8^{\mathrm{N} 18}$ (Supplementary Figure $7 \mathrm{~d}$ ) is typical of proteins with predominantly $\beta$-sheet structure. The $1 \mathrm{D} 88^{\mathrm{N} 18}$ is folded into a stable threedimensional structure, as shown by the cooperative thermal denaturation $\left(T_{\mathrm{m}} \approx 57{ }^{\circ} \mathrm{C}\right.$; Supplementary Figure $\left.7 \mathrm{e}\right)$. To understand the behavior and structure of $1 \mathrm{D} 8^{\mathrm{N} 18}$ in solution, we analyzed it in the absence of substrate using small-angle X-ray scattering (SAXS) (Fig. $2 \mathrm{~h}$ and Supplementary Figure 7f, g, Supplementary Table 2). The ab initio model shows how the homotrimer adopts a pyramidal conformation stabilized by direct interactions between the C-terminal TIE ${ }^{\mathrm{XVIII}}$ domains, as has previously been described for human collagen XVIII35. The 1D8 scFvs point orthogonally away from the plane defined by the trimerization domain without directly contacting each other, in a manner resembling an open tripod (Fig. 2h).

Design of an EGFR-targeted 4-1BB-agonistic trimerbody. We proceeded to generate a bispecific trimerbody by fusing the antihuman EGFR single-domain antibody $\left(\mathrm{V}_{\mathrm{HH}}\right.$; EGa1) ${ }^{32}$ to the Cterminus of $1 \mathrm{D} 8^{\mathrm{N} 18}$ through a 17 -residue-long linker giving the $1 \mathrm{D} 8^{\mathrm{N} / \mathrm{C}} \mathrm{EGa1}$ trimerbody (Fig. 1c). The construct was designed with a FLAG and a StrepII tag at the N-terminus of the $1 \mathrm{D} 8 \mathrm{scFv}$. The $1 \mathrm{D} 8^{\mathrm{N} / \mathrm{C}_{\mathrm{EGal}}}$ was produced in stably transfected HEK293 cells $(5 \mathrm{mg} / \mathrm{l})$, followed by Strep-Tactin affinity chromatography. SDS-PAGE analysis, under reducing conditions, of the purified protein revealed a single band with a molecular mass of $55.6 \mathrm{kDa}$ consistent with the calculated from its amino acid sequence (52.9 $\mathrm{kDa}$ without the signal sequence; Supplementary Figure $8 \mathrm{a}$ ). The oligomeric state of the purified $1 \mathrm{D} 8^{\mathrm{N} / \mathrm{C}} \mathrm{EGal}$ was examined by SEC-MALS measurements. The sample eluted as a major symmetric peak with a mass of $160 \mathrm{kDa}$, close to the calculated mass for a trimer without the signal sequence $(158.7 \mathrm{kDa})$, and a minor peak with a mass of $309 \mathrm{kDa}$ (Supplementary Figure 8b), which is indistinguishable from $1 \mathrm{D} 8^{\mathrm{N} / \mathrm{C}} \mathrm{EGa}$ by SDS-PAGE 
a

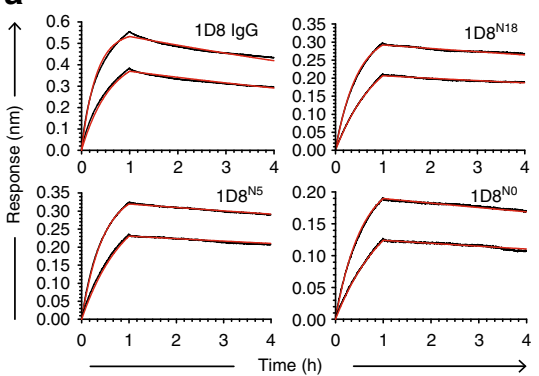

b

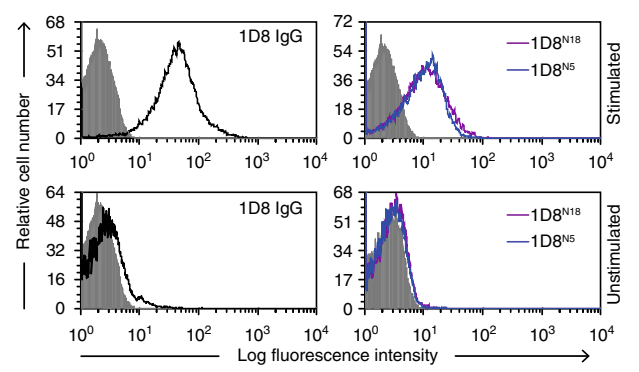

h

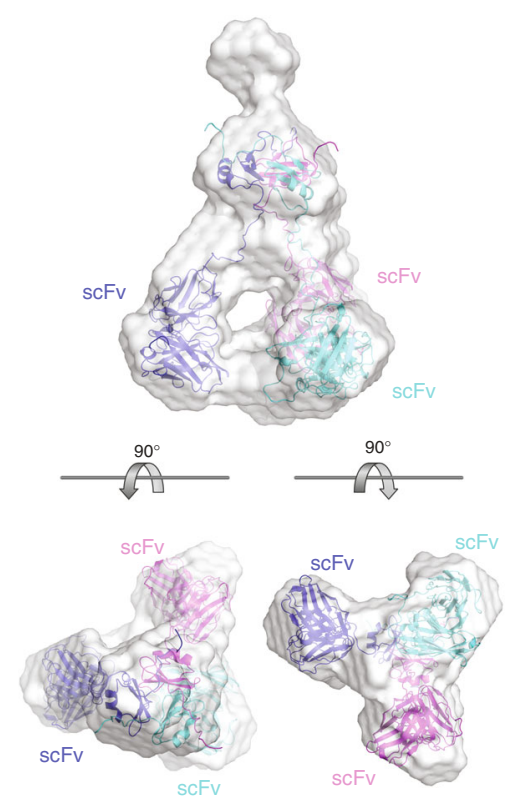

C

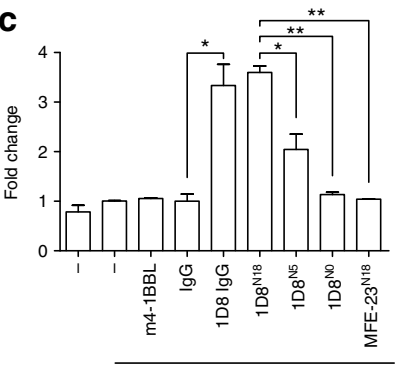

Anti-CD3 mAb

f
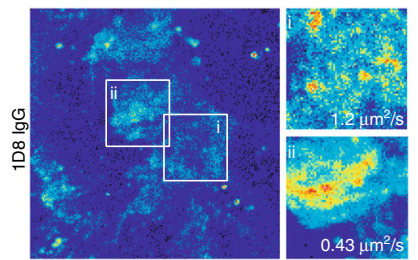

d

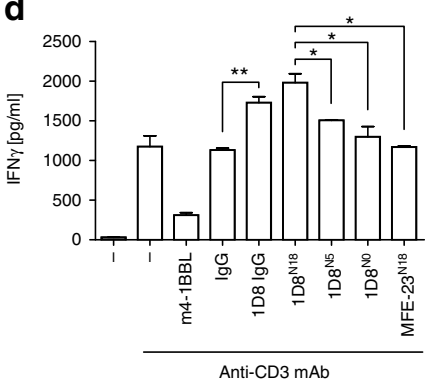

e

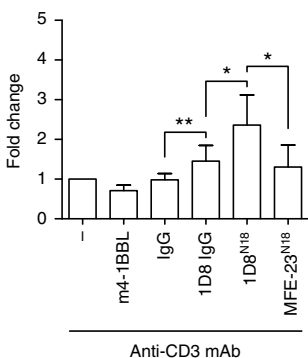

g
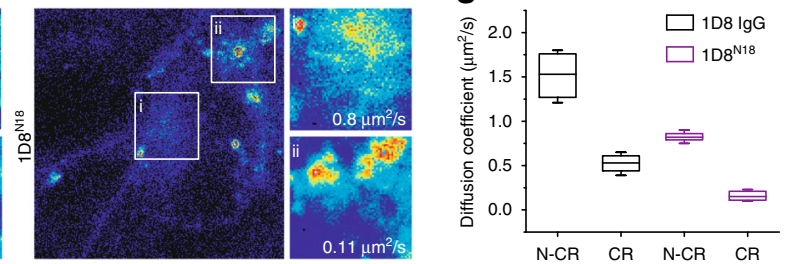

Fig. 2 Characterization of anti-4-1BB trimerbodies. a Sensorgrams (black curves) and fitting curves for 1D8 antibodies ( 2 and 4 nM), obtained by biolayer interferometry with surface-immobilized m4-1BB. $\mathbf{b}$ The binding to 4-1BB on the cell surface of stimulated mouse CD8a+ $\mathrm{T}$ cells measured by FACS. c-e Costimulatory activity of anti-4-1BB antibodies. Mouse CD8a+ $\mathrm{T}$ cells were stimulated with immobilized anti-CD3 mAb in the presence of m4-1BBL, $1 \mathrm{D} 8 \mathrm{N5}, 1 \mathrm{D} 8{ }^{\mathrm{N} 18}$, or $1 \mathrm{D} 8 \mathrm{lgG}$, and proliferation (c) and secretion of IFN- $\gamma(\mathbf{d})$ were measured after $48 \mathrm{~h}$ and cell viability (e) after $72 \mathrm{~h}$. Data are reported as fold change relative to the values obtained from anti-CD3 mAb-stimulated CD8a+ T cells. Rat lgG $2 \mathrm{a}$ and MFE-23N18 were used as controls. Data are mean $\pm \mathrm{SD}(n=3),{ }^{\star} P \leq 0.05,{ }^{\star \star} P \leq 0.01$, Student's $t$ test. $\mathbf{f}$ RICS analyses performed in living HEK293m4-1BB $-\mathrm{S}$ cells at regions containing clusters formed upon $1 \mathrm{D} 8 \mathrm{lgG}$ or $1 \mathrm{D} 8 \mathrm{N18}$ addition and at regions where clusters where not present (insert and zoomed-in regions ii, and i, respectively). Representative maximum intensity projection maps showing the RICS analyzed regions of interest. Values in the zoomed-in regions show the diffusion coefficient of bound antibody. The color heat map indicates in blueish tones the lower intensity and in redder tones the higher intensity. $\mathbf{g}$ Statistical analysis of the quantified diffusion coefficient obtained from 5 to 7 independent live cell experiments and 3-5 different regions of interest per cell ( $\mathrm{N}$-CR non-clustered region, CR clustered region). Data are presented as median (center line), upper and lower quartiles (boxes), and minimum-maximum (whiskers). h Arrangement of $1 \mathrm{D} 8$ N18 trimerbody in solution, as determined by SAXS. Rigid-body overlaying of the ab initio-determined SAXS envelope for 1D8 $\mathrm{N}^{18}$. The generated model (where each chain is colored in blue, magenta, or cyan) fits into the envelope (colored in pale gray)

(Supplementary Figure 8c). These results again indicate the formation of a minor population of dimers of trimers, as seen for $1 \mathrm{D} 8{ }^{\mathrm{N} 18}$. The two oligomeric species can be separated by SEC, and reinjection of the isolated major peak of trimers yields only a very minor peak at the elution volume of the trimer-dimers (Supplementary Figure $8 d$ ). $1 \mathrm{D} 88^{\mathrm{N} / \mathrm{C}} \mathrm{EGa1}$ performed very similarly to $1 \mathrm{D} 8^{\mathrm{N} 18}$ in $\mathrm{CD}$ and cooperative thermal denaturation studies (Supplementary Figure 8e, f). SAXS showed that $1 \mathrm{D} 8^{\mathrm{N} / \mathrm{C}_{\mathrm{EGa}}}$ contains the same trimerized TIEXVIII core seen for $1 \mathrm{D}^{\mathrm{N} 18}$. The binding domains, however, are distributed evenly around the plane defined by the TIE XVIII core (Fig. 3a and Supplementary Figure $8 \mathrm{~g}$, h, Supplementary Table 2), resembling a playground roundabout. Using the SAXS data and structural information from the protein data bank (PDB), we created a homology model intended to clarify the layout of the six binding domains around the core, as the linkers' length and flexibility permit several configurations, e.g., with the three 1D8 scFvs opposite the three EGal $V_{\mathrm{HH}}$ (as shown in Fig. 3a), or with alternating 1D8 and EGal domains side-by-side each other. Unfortunately, the obtained resolution is insufficient to distinguish between these possibilities, although the overall hexagonal structure is clearly defined in the ab initio SAXS model.

The functionality of the $1 \mathrm{D} 8^{\mathrm{N} / \mathrm{C}} \mathrm{EGal}$ was demonstrated by BLI. The $1 \mathrm{D} 8{ }^{\mathrm{N} / \mathrm{C}_{\mathrm{EGal}}}$ trimerbody has kinetic rate constants that are very similar to the $1 \mathrm{D} 8^{\mathrm{N}}$ trimerbodies in its interaction with immobilized m4-1BB (Fig. 3b, Supplementary Table 1). The binding kinetics of $1 \mathrm{D} 8^{\mathrm{N} / \mathrm{C}} \mathrm{EGal}$ to immobilized human EGFR-Fc chimera (hEGFR) was also investigated by BLI, and the interaction was found to also have a low picomolar $K_{\mathrm{D}}$ (Fig. 3b, Supplementary Table 1). Our previous comparison of EGa1 $\mathrm{V}_{\mathrm{HH}}$ and EGa1-derived N-trimerbody $\left(\mathrm{EGal}^{\mathrm{N}}\right)$ kinetics showed a low nanomolar $K_{\mathrm{D}}$ for the EGa1 $\mathrm{V}_{\mathrm{HH}}$ and a low picomolar $K_{\mathrm{D}}$ for $\mathrm{EGa1}^{\mathrm{N}} 36$. These kinetics are easily distinguishable, and $1 \mathrm{D} 8{ }^{\mathrm{N}}$ $\mathrm{C}_{\mathrm{EGal}}$ showed comparable kinetics to $\mathrm{EGal}^{\mathrm{N}}$, indicating that it trivalently binds hEGFR. The $1 \mathrm{D} 8^{\mathrm{N} / \mathrm{C}} \mathrm{EGal}$ was found to be capable of binding immobilized $\mathrm{m} 4-1 \mathrm{BB}$ and hEGFR simultaneously (Fig. 3c). This further demonstrates the bispecificity of $18^{\mathrm{N}} / \mathrm{C} \mathrm{EGa}$ and shows a lack of steric hindrance between 
a

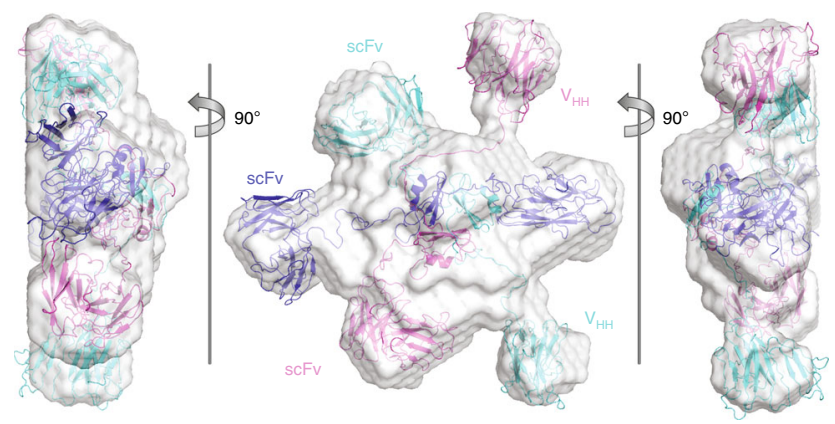

e

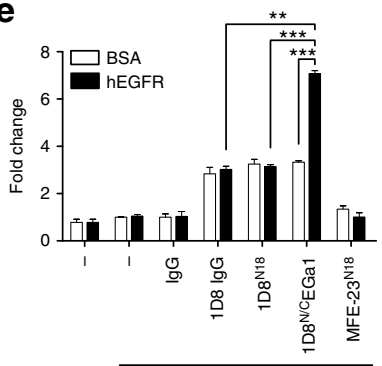

Anti-CD3 mAb f

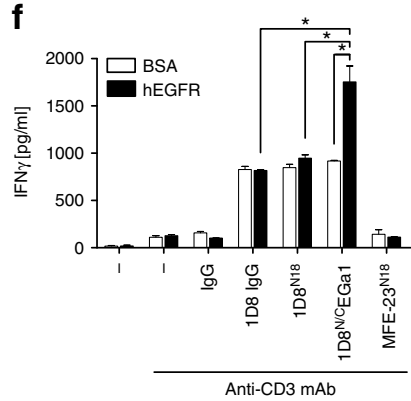

b
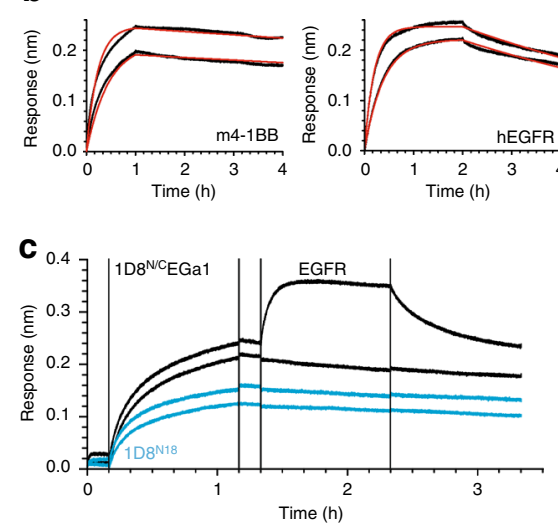

d

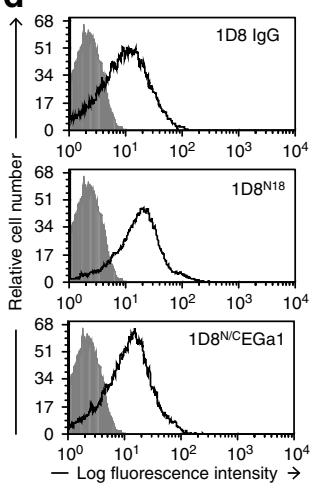

g

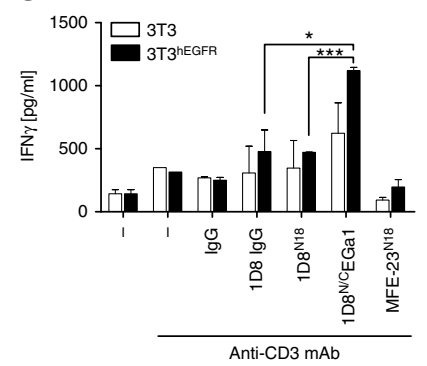

h

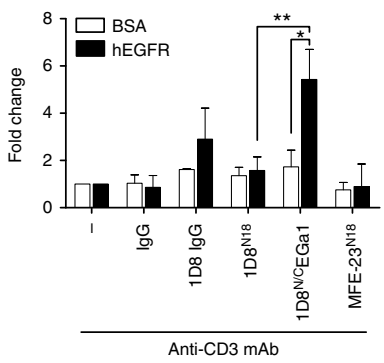

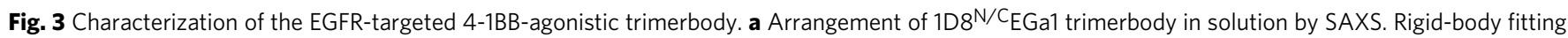
of the model corresponding to $1 \mathrm{D} 8{ }^{\mathrm{NC}} \mathrm{EGa1}$ inside the SAXS envelope (colored in pale gray). Each chain has been colored in blue, magenta, or cyan. b Sensorgrams (black curves) and the results of fitting to a 1:1 model (red curves) obtained using biolayer interferometry for the interaction of 1D8 ${ }^{N / C_{E G}}{ }_{1}$

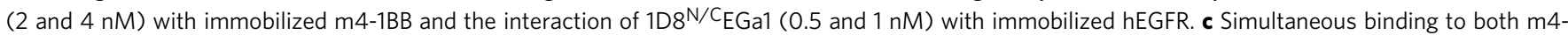
$1 \mathrm{BB}$ and hEGFR was demonstrated for $1 \mathrm{D} 8^{\mathrm{N} / \mathrm{C}} \mathrm{EGa1}$ but not $1 \mathrm{D} 8^{\mathrm{N} 18}$. Biosensors were coated with m4-1BB, after which $4 \mathrm{nM}$ of $1 \mathrm{D} 8^{\mathrm{N} / \mathrm{C}} \mathrm{EGa1}$ (black curves) or $1 \mathrm{D} 88^{\mathrm{N} 18}$ (blue curves) were added. $\mathbf{d}$ The binding of anti-4-1BB antibodies to $\mathrm{m} 4-1 \mathrm{BB}$ on the cell surface of stimulated mouse CD8a+ $\mathrm{T}$ cells measured by FACS. e, - $\mathbf{f}$ Mouse CD8a ${ }^{+}$T cells were plated with immobilized anti-CD3 mAb and hEGFR or BSA in the presence of 1D8 $8^{\mathrm{N} 18}$, 1D8 ${ }^{\mathrm{N} / \mathrm{C}_{\mathrm{EG}}}$ 1, or $1 \mathrm{D} 8$ IgG, and proliferation (e) and IFN- $\gamma$ secretion (f) were determined after $48 \mathrm{~h}$. EGFR-negative 3 T3 cells or EGFR-positive 3 T3 3 hEGF cells were co-cultured with mouse CD8 $a^{+}$T cells in the presence of anti-CD3 mAb and 1D8 ${ }^{\mathrm{N} 18}, 1 \mathrm{D} 8^{\mathrm{N}} / \mathrm{C}$ EGa1, or $1 \mathrm{D} 8 \mathrm{IgG}$. IFN- $\gamma$ secretion analyzed after $48 \mathrm{~h}(\mathbf{g})$ and cell viability after $72 \mathrm{~h}$ (h). Data are represented as fold change relative to the values obtained from anti-CD3 mAb stimulated cells. Rat IgG 2 and MFE-23 18 were used as negative controls. Data are mean $\pm \operatorname{SD}(n=3),{ }^{\star} P \leq 0.05,{ }^{\star \star} P \leq 0.01,{ }^{\star \star \star} P \leq 0.001$, Student's $t$ test

its interactions with hEGFR and $\mathrm{m}-4-1 \mathrm{BB}$. The ability of $1 \mathrm{D} 8^{\mathrm{N} / \mathrm{C}} \mathrm{EGa1}$ to detect its antigens as cell surface proteins was studied by flow cytometry. The $1 \mathrm{D} 8^{\mathrm{N} / \mathrm{C}} \mathrm{EGal}$ trimerbody bound to HEK293 (EGFR+), to HEK293 ${ }^{\text {m4-1BB }}$ cells, and to mouse 3 T3 cells expressing human EGFR (3T3 ${ }^{\text {hEGFR }}$ ) but not to wild-type 3T3 cells (Supplementary Figure 9). Furthermore, 1D8 ${ }^{\mathrm{N} / \mathrm{C}_{\mathrm{EGa}}}$ bound to activated mouse CD8a ${ }^{+} \mathrm{T}$ cells as efficiently as the $1 \mathrm{D} 8^{\mathrm{N} 18}$ (Fig. 3d). To further assess the multivalent binding of $1 \mathrm{D} 8{ }^{\mathrm{N} / \mathrm{C}} \mathrm{EGa1}$, we studied its capacity to inhibit proliferation and EGFR phosphorylation in A431 cells ${ }^{32}$. 1D8 ${ }^{\mathrm{N} / \mathrm{C}} \mathrm{EGal}$ and cetuximab, an EGF-competitive inhibitor ${ }^{37}$, but neither the anti-human CD20 rituximab nor 1D8 IgG, inhibited A431 proliferation, in a dose-dependent manner $(P \leq 0.0001$ for the higher doses of both antibodies, vs. equimolar doses of control antibodies; Supplementary Figure 10a), and EGFR phosphorylation (Supplementary Figure 10b).

We then wanted to determine whether $1 \mathrm{D} 8^{\mathrm{N} / \mathrm{C}} \mathrm{EGa1}$ retained the baseline costimulatory capacity seen for $1 \mathrm{D} 8^{\mathrm{N} 18}$ and whether this was improved by the crosslinking provided through EGal's binding to hEGFR. CD8a ${ }^{+} \mathrm{T}$ cells were stimulated with immobilized anti-CD3 $\mathrm{mAb}$ and the panel of costimulatory agents in solution, in the presence or absence of plasticimmobilized hEGFR. The $1 \mathrm{D} 8^{\mathrm{N} / \mathrm{C}} \mathrm{EGa1}$ had a costimulatory effect similar to $1 \mathrm{D} 8^{\mathrm{N} 18}$ in the absence of hEGFR, but proliferation $(P=0.0008)$ and IFN- $\gamma$ levels $(P=0.0198)$ were greatly enhanced when hEGFR was included (Fig. 3e, f). This effect was further confirmed by co-culture assays using EGFRnegative and EGFR-positive target cells. The IFN- $\gamma$ levels were significantly higher when $\mathrm{CD} 8 \mathrm{a}^{+} \mathrm{T}$ cells were co-cultured with $3 \mathrm{~T} 3^{\mathrm{hEGFR}}$ in the presence of the $1 \mathrm{D} 8^{\mathrm{N}} / \mathrm{C} \mathrm{EGa}$, as compared to the non-targeted 1D8 molecules $(P=0.03441 \mathrm{D} 8 \mathrm{IgG}$, and $P=$ $0.00091 \mathrm{D} 8^{\mathrm{N} 18}$; Fig. $\left.3 \mathrm{~g}\right)$. We then investigated the effect of EGFRtargeted 4-1BB costimulation on cell viability. After $72 \mathrm{~h}$, a statistically significant increased viability of $\mathrm{CD}^{+} \mathrm{a}^{+} \mathrm{T}$ cells costimulated with $1 \mathrm{D} 8{ }^{\mathrm{N} / \mathrm{C}} \mathrm{EGa}$ in the presence of plasticimmobilized hEGFR was observed $(P=0.0326)$, as compared to cells costimulated with $1 \mathrm{D} 88^{\mathrm{N} 18}(P=0.0088$; Fig. $3 \mathrm{~h})$.

The EGFR-targeted trimerbody shows high tumor localization. First, we studied the serum stability of $1 \mathrm{D} 8^{\mathrm{N} 18}$ and $1 \mathrm{D} 8^{\mathrm{N} / \mathrm{C}} \mathrm{EGa1}$, and no significant loss of 4-1BB- or EGFR-binding activity was detected even after 7 days in mouse serum at $37^{\circ} \mathrm{C}$ (Supplementary Figure 11a, b). Pharmacokinetic studies were performed in immunocompetent mice, which received a single intravenously (i.v.) injection of the anti-4-1BB antibodies. The serum concentrations of active protein were determined by ELISA with immobilized $\mathrm{m} 4-1 \mathrm{BB}$. In CD-1 mice, the $1 \mathrm{D} 8^{\mathrm{N} 18}$ was rapidly cleared from circulation with a terminal half-life of $1.3 \mathrm{~h}$, whereas the $1 \mathrm{D} 8^{\mathrm{N} / \mathrm{C}} \mathrm{EGa1}$ showed a prolonged circulatory half-life of $16.1 \mathrm{~h}$ (Fig. 4a, Supplementary Table 3). 1D8 ${ }^{\mathrm{N} / \mathrm{C}_{\mathrm{EGal}}}$ serum halflife was not influenced by the genetic background of the mice, and 

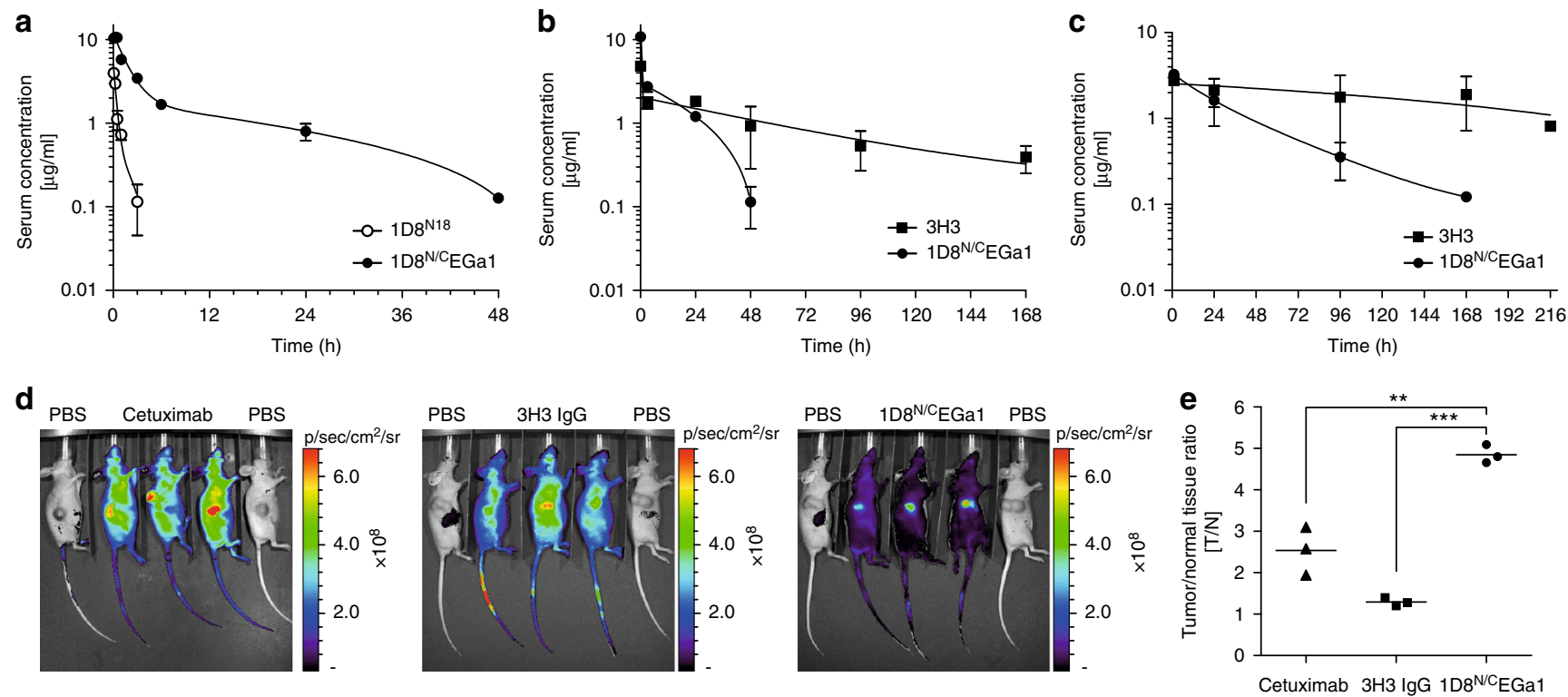

Fig. 4 Pharmacokinetic properties and tumor imaging of the EGFR-targeted 4-1BB-agonistic trimerbody. Pharmacokinetic studies after a single i.v. dose

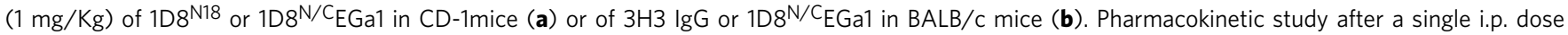
$\left(1 \mathrm{mg} / \mathrm{Kg}\right.$ ) of $3 \mathrm{H} 3 \mathrm{lgG}$ or $1 \mathrm{D} 8 \mathrm{~N} / \mathrm{C}_{\mathrm{EGa}}$ in BALB/c mice (c). $\mathbf{d}$ In vivo fluorescence imaging of $\mathrm{A} 431$ tumor-bearing nude mice $24 \mathrm{~h}$ after i.v. injection of PBS or $100 \mu \mathrm{g}$ of Cy5-labeled cetuximab, CF647-labeled 3H3 lgG or CF647-labeled 1D8 $8^{\mathrm{N} / \mathrm{C}}$ EGa1. e Tumor to normal tissue (T/N) ratios. The color scale bar represents the fluorescence intensity recorded as photons per second per centimeter squared per steradian $\left(\mathrm{p} / \mathrm{s} / \mathrm{cm}^{2} / \mathrm{sr}\right)$. Data are mean $\pm \mathrm{SD}(n=3)$, ${ }^{\star \star} P \leq 0.01,{ }^{\star \star \star} P \leq 0.001$, Student's $t$ test

a similar pharmacokinetic profile was observed in BALB/c mice (Fig. 4b, Supplementary Table 4). The half-life of the anti-4-1BB $\mathrm{mAb} 3 \mathrm{H} 33^{33}$ was 4.8 days, consistent with published data ${ }^{38}$ (Fig. $4 \mathrm{~b}$, Supplementary Table 4). After a single intraperitoneal (i.p.) injection in $\mathrm{BALB} / \mathrm{c}$ mice, the half-lives of $1 \mathrm{D} 8^{\mathrm{N} / \mathrm{C}} \mathrm{EGa}$ and $3 \mathrm{H} 3$ IgG were $32 \mathrm{~h}$ and 7 days, respectively (Fig. 4c, Supplementary Table 5). For in vivo imaging, $3 \mathrm{H} 3 \mathrm{IgG}, 1 \mathrm{D} 8^{\mathrm{N} / \mathrm{C}} \mathrm{EGa} 1$, and the anti-EGFR mAb cetuximab were labeled with near-infrared (NIR) fluorochromes, which did not change their SDS-PAGE migration or compromise their binding to cell surface antigen (Supplementary Figure 12). Athymic nude mice bearing hEGFR-positive A431 tumor xenografts subcutaneously (s.c.) implanted into the right flank were i.v. injected in the tail vein with NIR-labeled antibodies and imaged $24 \mathrm{~h}$ later (Fig. 4d). The $1 \mathrm{D} 8^{\mathrm{N} / \mathrm{C}_{\mathrm{EGa}} 1}$ trimerbody showed high tumor localization with a tumor to normal tissue $(\mathrm{T} / \mathrm{N})$ ratio of $4.85 \pm 0.13$ (mean $\pm \mathrm{SD}$ ), as compared to that of cetuximab $(2.54 \pm 0.34)(P \leq 0.01)$ and $3 \mathrm{H} 3 \mathrm{IgG}$ $(1.29 \pm 0.06)(P \leq 0.0001)$, which corresponds to little to no specific tumor accumulation (Fig. 4 d, e).

Antitumor activity of EGFR-targeted 4-1BB-agonistic trimerbody. To study the antitumor effects of the EGFR-targeted 41BB-agonistic trimerbody in immune competent mice, we used murine CT26 colorectal carcinoma (H-2d) cells infected with retrovirus encoding human EGFR (CT26 ${ }^{\text {EGFR }}$ ) (Supplementary Figure 13a). The in vitro cell proliferation rates and the in vivo take rate and growth curves in BALB/c mice of CT26hEGFR cells and CT26 ${ }^{\text {mock }}$ cells infected with empty vector retroviruses were similar (Supplementary Figure 13b, c), suggesting that the expression of hEGFR did not significantly alter the poor immunogenicity of the CT26 tumor cells. Furthermore, ex vivo isolated CT26 ${ }^{\text {hEGFR }}$ cells from 3 -week-old s.c. tumors expressed significant levels of surface hEGFR (Supplementary Figure 13d). To elucidate the functionality of the EGFR pathway in CT26 hEGFR cells, we studied the capacity of cetuximab and $1 \mathrm{D} 8^{\mathrm{N} / \mathrm{C}} \mathrm{EGal}$ to inhibit their proliferation. As shown in Supplementary Figure 13e, neither cetuximab nor $1 \mathrm{D} 88^{\mathrm{N} / \mathrm{C}} \mathrm{EGa1}$ had a significant effect on CT26 $6^{\text {hEGFR }}$ proliferation $(P=0.6647$ and $P=0.0760$ respectively, for higher dose, vs. equimolar dose of control antibody). Therefore, the potential therapeutic effect of $1 \mathrm{D} 8{ }^{\mathrm{N} / \mathrm{C}} \mathrm{EGa} 1$ is not contributed by an EGa1-mediated antiproliferative effect. We used an established regimen to administer IgG-based 4-1BBagonistic mAbs and the EGFR-targeted 4-1BB-agonistic trimerbody, with three i.p. injections at 2-day intervals ${ }^{15}$. Injection of purified $1 \mathrm{D} 8^{\mathrm{N} / \mathrm{C}} \mathrm{EGa}$ in mice bearing established CT26 6 HEGFR tumors (average diameter of $0.4 \mathrm{~cm}$ ) induced tumor regression in 8 out of $10(80 \%)$ mice in two separate experiments (Fig. 5a, b). Treatment with the IgG-based $4-1 \mathrm{BB}$ agonist antibodies 1D8 (Fig. $5 \mathrm{a}$ ) or $3 \mathrm{H} 3$ (Fig. $5 \mathrm{~b}$ ) resulted in complete regression in 10

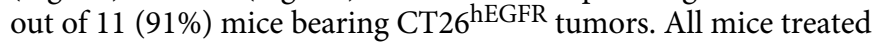
with phosphate-buffered saline (PBS), control antibodies (isotype control rat $\operatorname{IgG}_{2 \mathrm{a}}$ and $\left.\mathrm{MFE}-23^{\mathrm{N} 18}\right)$, and $1 \mathrm{D} 8^{\mathrm{N} 18}$ were sacrificed within 4-5 weeks after tumor cell implantation (Fig. 5a, b). It is well established that mice cured by IgG-based 4-1BB-agonistic $\mathrm{mAb}$ treatment have long-lasting and tumor-specific immunity ${ }^{39-41}$. To investigate whether the EGFR-targeted 4-1BBagonistic trimerbody can generate a similar effect, mice that rejected the implanted CT26hEGFR tumor by treatment with $3 \mathrm{H} 3$ IgG or $1 \mathrm{D}^{\mathrm{N} / \mathrm{C}} \mathrm{EGa1}$ (Fig. 5b) were rechallenged 50 days later with CT26 $6^{\text {mock }}$ cells. $3 \mathrm{H} 3$ IgG- and $1 \mathrm{D} 8^{\mathrm{N} / \mathrm{C}} \mathrm{EGa1-cured} \mathrm{mice}$ ( $P=0.0027$ and $P=0.0067$, respectively), but not age-matched naive mice, were resistant to a rechallenge with CT26 $6^{\text {mock }}$ tumor cells (Fig. 5c and Supplementary Figure 14), showing that the trimerbody-mediated EGFR-targeted 4-1BB costimulation can induce long-term protective immunological memory against CT26 tumors that do not express hEGFR. In order to understand the antitumor immune response generated with $4-1 \mathrm{BB}$ antibodies, tumors from $3 \mathrm{H} 3$ IgG- and $1 \mathrm{D} 8^{\mathrm{N}} / \mathrm{C}_{\mathrm{EGa}}$-treated mice and control mice were extracted 2 days after receiving the third i.p dose (day 13 after tumor inoculation) (Supplementary Figure 15) for immunohistochemistry to quantify tumorinfiltrating CD8 $+\mathrm{T}$ lymphocytes (TILs). The percentage of $\mathrm{CD}^{+}$TILs was an order of magnitude higher in $3 \mathrm{H} 3$ IgG- and 

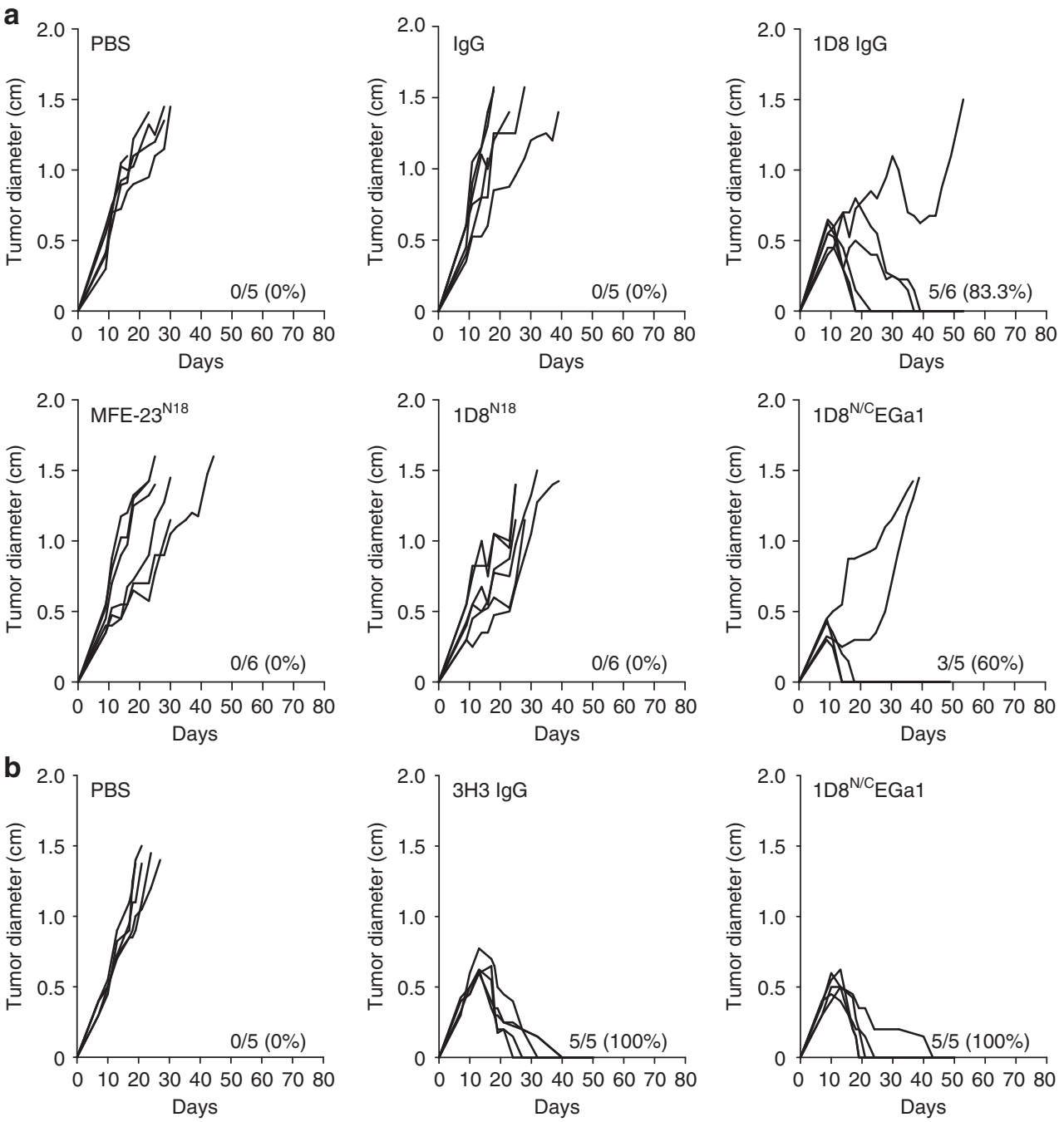

C

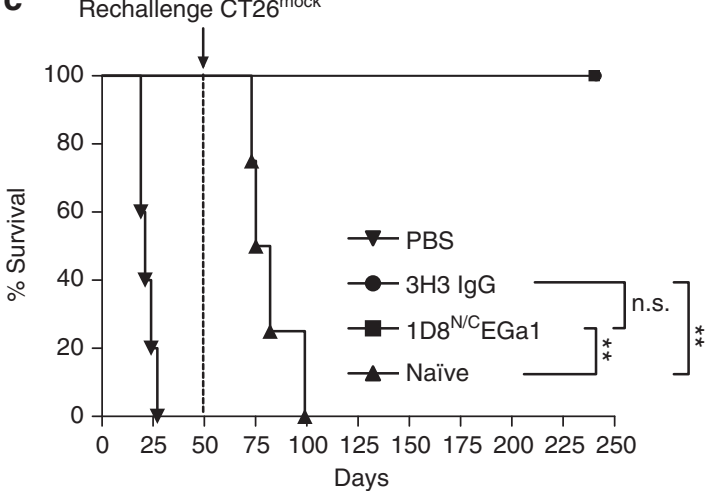

d

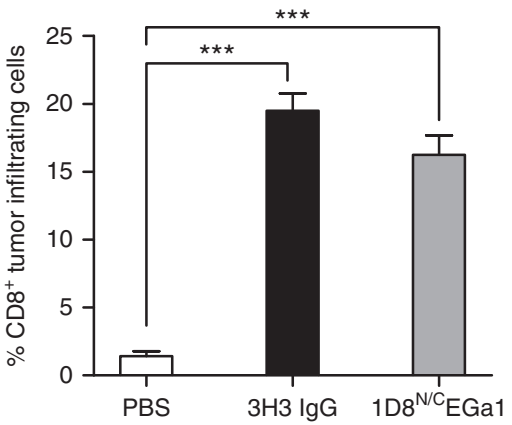

Fig. 5 Induction of tumor regression in mice treated with $1 \mathrm{D} 8^{\mathrm{N}} / \mathrm{C}_{\mathrm{EG}} \mathrm{a}$ trimerbody. a BALB/c mice inoculated s.c. with CT26 hEGFR tumor cells ( $n=6 /$ group) were treated with three i.p. doses $\left(4 \mathrm{mg} / \mathrm{kg}\right.$ ) of rat $\lg \mathrm{G}_{2 a}$ isotype, $1 \mathrm{D} 8 \mathrm{IgG}, \mathrm{MFE}-23^{\mathrm{N} 18}, 1 \mathrm{D} 8^{\mathrm{N} 18}, 1 \mathrm{D} 8^{\mathrm{N}} / \mathrm{C}_{\mathrm{EGa1}}$, or with PBS and monitored for tumor growth. Tumor diameter growth curves for individual mice in each treatment group are presented. The results are representative of two experiments identically performed. b BALB/c mice bearing CT26 $6^{\text {hEGFR }}$ tumors ( $n=5$ /group) were treated with three i.p. doses of either PBS, $3 \mathrm{H} 3$ IgG, or $1 \mathrm{D} 8{ }^{\mathrm{N} / \mathrm{C}} \mathrm{EGa1}$. c Kaplan-Meier survival curves of the $1 \mathrm{D} 8{ }^{\mathrm{N}} / \mathrm{C}_{\mathrm{EGa}}$ trimerbody-treated mice ${ }^{\star \star} P \leq 0.01$ ), log-rank (Mantel-Cox) test. Long-term survivors, following complete tumor rejection (b) were rechallenged with $\mathrm{CT} 26^{\text {mock }}$ cells (s.c.) 50 days after i.p. injections of $3 \mathrm{H} 3$ IgG or $1 \mathrm{D} 8 \mathrm{~N} / \mathrm{C}_{\mathrm{EG}} 1 \mathrm{trimerbody}$. As a control group, tumor naive mice developed tumors in every case. d Quantitative analysis of intratumoral CD8 ${ }^{+} \mathrm{T}$ cells in paraffin-embedded mouse tumor tissue ( $n=3$ /group) by immunohistochemistry. Data were calculated as percentage of CD $8^{+}$versus total cell number and presented as mean \pm SD. ${ }^{\star \star \star} P \leq$ 0.001 , Student's $t$ test 
a
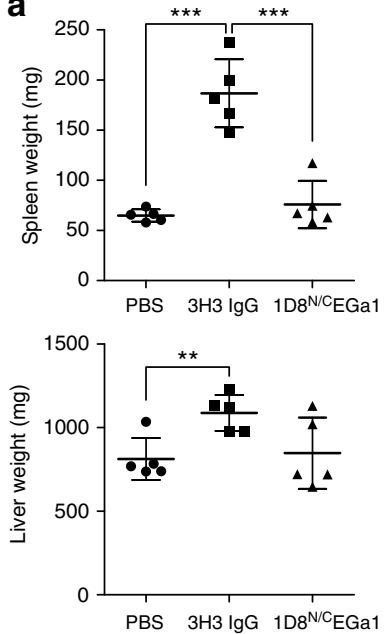

b

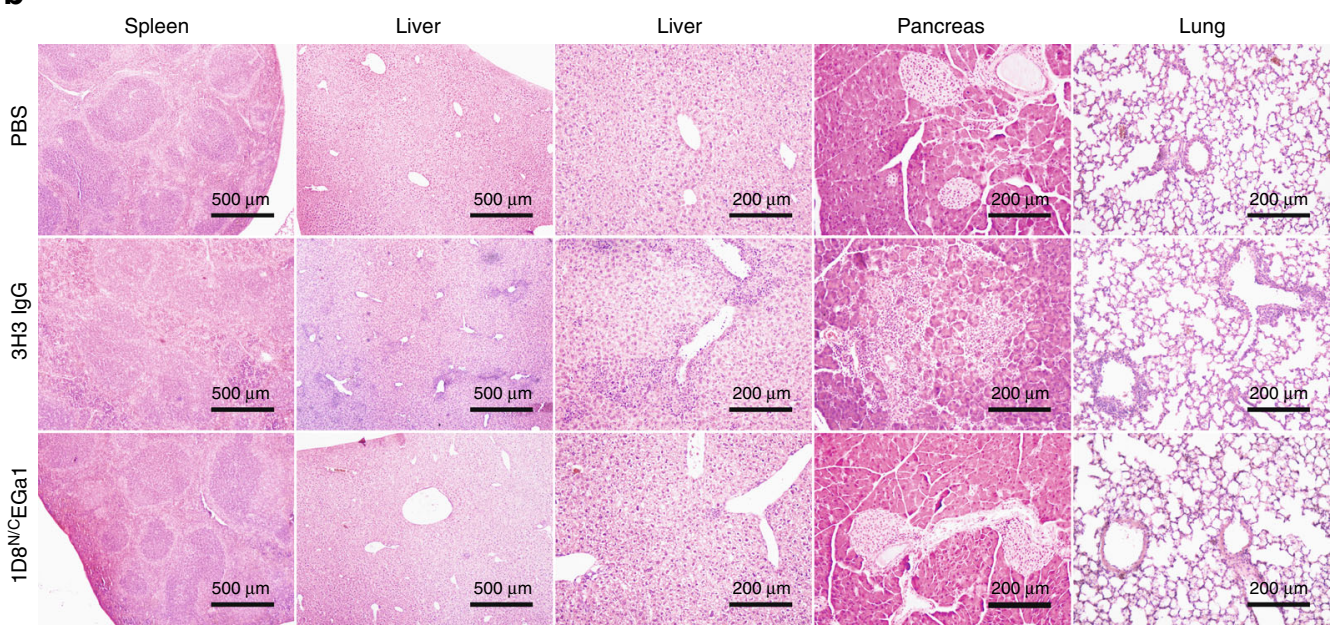

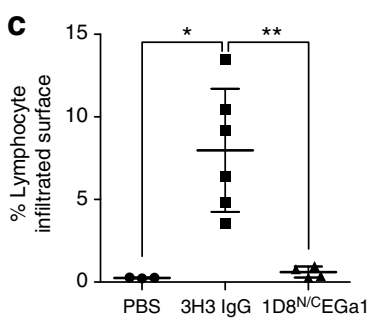
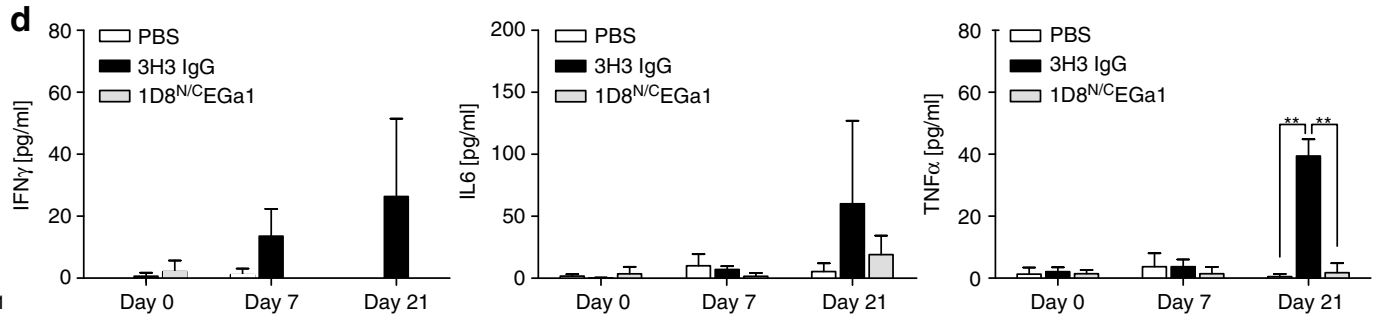

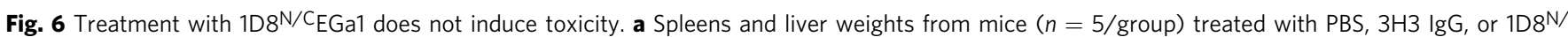
$C_{E G a 1 . ~}$ Hematoxylin and eosin staining of representative tissue slides from the spleen, liver, pancreas, and lung of mice treated with PBS, $3 \mathrm{H} 3 \mathrm{lgG}$, and $1 \mathrm{D} 8{ }^{\mathrm{N} / \mathrm{C}} \mathrm{EGa1}$. Magnification is $\times 40$ (spleen and liver) and $\times 200$ (liver, pancreas, and lung). Scale bars are shown. $\mathbf{c}$ Quantification of the mononuclear cell-

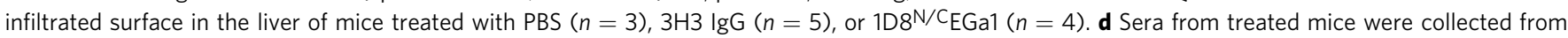
peripheral blood at days 0,7 , and 21 of treatment, and levels of INF- $\gamma$, TNF- $\alpha$, and IL- 6 were measured by luminex assays $(n=3$ per time point). All data are presented as mean \pm SD. $P$ values $\left({ }^{\star} P \leq 0.05,{ }^{\star *} P \leq 0.01,{ }^{\star \star \star} P \leq 0.001\right)$ were calculated with Student's $t$ test

$1 \mathrm{D} 8^{\mathrm{N} / \mathrm{C}} \mathrm{EGa1}$-treated mice $(19.48 \pm 1.28$ and $16.25 \pm 1.41$, respectively) compared to the PBS-treated mice $(1.42 \pm 0.36)$ (Fig. 5d and Supplementary Figure 16), indicating an efficient tumor recruitment of $\mathrm{CD}^{+} \mathrm{T}$ lymphocytes in the antibodytreated mice.

EGFR-targeted 4-1BB-agonistic trimerbody shows negligible toxicity. We compared the toxicity profile of ${ }_{1 D} 8^{\mathrm{N} / \mathrm{C}} \mathrm{EGa} 1$ directly with $3 \mathrm{H} 3 \mathrm{IgG}$ under similar conditions. Mice were injected i.p. with PBS, $3 \mathrm{H} 3 \mathrm{IgG}$, or $1 \mathrm{D} 8^{\mathrm{N} / \mathrm{C}} \mathrm{EGa1}(6 \mathrm{mg} / \mathrm{kg})$ once a week for 3 weeks and euthanized 1 week later. As shown in Fig. 6a, treatment with $3 \mathrm{H} 3 \mathrm{IgG}$ resulted in gross enlargement of spleen and livers as demonstrated by weight $(P \leq 0.0001$ and $P=$ 0.0058 , respectively). In contrast, treatment with $1 \mathrm{D} 8^{\mathrm{N} / \mathrm{C}} \mathrm{EGa} 1 \mathrm{did}$ not result in splenomegaly or hepatomegaly (Fig. 6a). The histologic study of the spleens of mice treated with $3 \mathrm{H} 3 \mathrm{IgG}$ revealed an altered architecture with expanded follicles with undefined zones and clear evidence of extramedullary hematopoiesis (Fig. 6b), as previously described ${ }^{14}$. In contrast, the spleens of mice treated with $1 \mathrm{D} 8^{\mathrm{N} / \mathrm{C}} \mathrm{EGal}$ showed normal histology (Fig. 6b). Also confirming previous results ${ }^{14,15}$, treatment with 3H3 IgG caused significant mononuclear cell infiltration in the liver, forming periportal cuffs with thickening of tunica media and also infiltration foci associated with microvasculature, while no significant infiltration was observed in mice treated with $1 \mathrm{D} 8{ }^{\mathrm{N} / \mathrm{C}} \mathrm{EGa} 1$ (Fig. 6b). Indeed, the surface of infiltrating mononuclear cells accounted for $8 \%$ of the liver of mice treated with $3 \mathrm{H} 3 \mathrm{IgG}$, while it only represented $0.6 \%$ in mice treated with $1 \mathrm{D} 8^{\mathrm{N} / \mathrm{C}} \mathrm{EGa} 1(P=0.0048)$ and $0.25 \%$ in mice treated with $\mathrm{PBS}$
$(P=0.0104)$ (Fig. 6c). In addition, staining of collagen fibers with sirius red (Supplementary Figure 17) or Masson's trichrome (Supplementary Figure 18) showed that $3 \mathrm{H} 3 \mathrm{IgG}$ treatment, but not $1 \mathrm{D} 8^{\mathrm{N} / \mathrm{C}} \mathrm{EGa1}$, caused the deposition and disarrayment of portal collagen fibers, indicative of an early stage of fibrosis. Mononuclear cell infiltration was also seen in the lungs, forming perivascular cuffs, and in pancreas of $3 \mathrm{H} 3 \mathrm{IgG}$-treated mice. Pancreas infiltration radiated from the vasculature and extended to the neighboring intercalated ducts (Fig. 6b). Prominent collagen deposition in the infiltrated areas of the pancreas of mice treated with $3 \mathrm{H} 3 \mathrm{IgG}$ was observed, indicative of fibrosis. In contrast, none of these features were observed in mice treated with $1 \mathrm{D} 8{ }^{\mathrm{N} / \mathrm{C}} \mathrm{EGa1}$ (Supplementary Figure 17 and 18). The effects of treatment with $3 \mathrm{H} 3 \mathrm{IgG}$ and $1 \mathrm{D} 8^{\mathrm{N} / \mathrm{C}_{\mathrm{EG}}} \mathrm{El}$ on the levels of proinflammatory cytokines in serum were also compared. As shown in Fig. 6d, $3 \mathrm{H} 3 \mathrm{IgG}$ treatment triggered significant elevation of INF- $\gamma$, IL- 6 , and TNF- $\alpha\left(P=0.0055\right.$ PBS, and $P=0.00151{ }^{2} 8^{\mathrm{N} /}$ $\left.\mathrm{C}_{\mathrm{EGa}}\right)$, particularly evident at day 21 . In contrast, $1 \mathrm{D} 8^{\mathrm{N} / \mathrm{C}_{\mathrm{EGa}}}$ induced minimal or undetectable levels of inflammatory cytokines comparable to PBS-treated animals.

In order to investigate whether $1 \mathrm{D} 8^{\mathrm{N} / \mathrm{C}} \mathrm{EGa1}$ 's shorter half-life might be responsible for its lack of toxicity, another study was conducted in $\mathrm{BALB} / \mathrm{c}$ mice in which $1 \mathrm{D} 8^{\mathrm{N} / \mathrm{C}} \mathrm{EGa}$ was administered $(6 \mathrm{mg} / \mathrm{kg})$ i.p. every 3 or 4 days, for 3 weeks, for a total of six doses. These more frequent injections were intended to maintain circulatory levels of $1 \mathrm{D} 8^{\mathrm{N} / \mathrm{C}} \mathrm{EGa}$ comparable to those of the longer-circulating $3 \mathrm{H} 3 \mathrm{IgG}$, which was injected as before with 6 $\mathrm{mg} / \mathrm{kg}$ i.p injections once weekly for 3 weeks. The escalated $1 \mathrm{D} 8^{\mathrm{N} /}$ $\mathrm{C}_{\mathrm{EGal}}$ regimen did not induce splenomegaly or hepatomegaly, nor significant histological alterations, while the standard $3 \mathrm{H} 3$ 
IgG regimen induced alterations similar to those observed in $3 \mathrm{H} 3$ IgG-treated C57BL/6 mice (Supplementary Figure 19).

\section{Discussion}

In this study, we describe a tumor-targeted 4-1BB agonist trimerbody with similar efficacy and less toxicity than conventional IgG-based 4-1BB-agonistic antibodies. This hexavalent trimerbody consists of three anti-4-1BB scFvs and three anti-EGFR single-domain antibodies organized around a modified homotrimerization domain from collagen XVIII. More than $80 \%$ of its mass is directly involved in antigen binding. While the monospecific trivalent $1 \mathrm{D} 8^{\mathrm{N} 18}$ trimerbody adopts a tripod-shaped conformation, the addition of the anti-EGFR $\mathrm{V}_{\mathrm{HH}}$ antibodies into the bispecific hexavalent $1 \mathrm{D} 8^{\mathrm{N} / \mathrm{C}} \mathrm{EGa1}$ trimerbody changes the conformation to an extended and planar hexagram-shaped structure with the six binding domains exposed at the periphery. This structure is inherently flexible, and the SAXS ab initio model supports a dynamic equilibrium of the open conformation where the binding domains are not locked into place relative to the core but instead exist in various extended conformations. These structural findings, when considered alongside the high avidity observed in characterization of $1 \mathrm{D} 8{ }^{\mathrm{N} / \mathrm{C}} \mathrm{EGal}$ 's binding to biosensor- and cell surface-displayed $4-1 \mathrm{BB}$, indicate that the binding domains are predominantly sterically unhindered and available for antigen binding.

The $1 \mathrm{D} 8^{\mathrm{N} / \mathrm{C}} \mathrm{EGa} 1$ trimerbody is efficiently expressed by transfected human cells as soluble protein and can be purified using standard affinity chromatographic methods. SEC-MALS showed that both $1 \mathrm{D} 8^{\mathrm{N} 18}$ and $1 \mathrm{D} 8^{\mathrm{N} / \mathrm{C}} \mathrm{EGal}$ trimerbodies primarily formed the expected trimeric structure, with a minor fraction forming higher-order oligomers (likely trimer-dimers). This effect was not observed with either $\mathrm{EGal} \mathrm{V}_{\mathrm{HH}}$-based trimerbodies ${ }^{36,42}$ or non-1D8 scFv-based trimerbodies ${ }^{31,43}$ and is therefore likely attributable to the 1D8 scFv. The partial dimerization of $\mathrm{scFvs}^{44}$ and clustering behavior of certain scFvs in particular ${ }^{45}$ have previously been reported, so this is not a new phenomenon.

The binding experiments provide quantitative evidence for trimeric interactions between the $1 \mathrm{D} 8^{\mathrm{N} / \mathrm{C}_{\mathrm{EGal}}}$ trimerbody and both EGFR and 4-1BB. This $3: 3$ stoichiometry of the $1 \mathrm{D} 88^{\mathrm{N} /}$ $\mathrm{C}_{\mathrm{EGa}}$ trimerbody is unique among the existing body of 4-1BBbinding proteins, including $4-1 \mathrm{BBL}$ fusion proteins ${ }^{25}$. We have provided evidence that, upon binding of soluble 4-1BBL to cell surface-displayed $4-1 \mathrm{BB}$, the complex is rapidly internalized, whereas the anti-4-1BB antibodies induced the formation of durable clusters. The amount and stability of the 4-1BB clusters are significantly higher upon interaction with trivalent $1 \mathrm{D} 88^{\mathrm{N} 18}$ trimerbody than with bivalent 1D8 IgG, and this, along with the increased avidity for EGFR, could explain the increased costimulation induced by $1 \mathrm{D} 8^{\mathrm{N} / \mathrm{C}} \mathrm{EGal}$. The bispecific trimerbody demonstrated better costimulation of $\mathrm{CD} 8 \mathrm{a}^{+} \mathrm{T}$ cells in the presence of human EGFR, either immobilized or expressed in a cell surface context. These results support the $1 \mathrm{D} 8^{\mathrm{N} / \mathrm{C}} \mathrm{EGa1}$ trimerbody-induced formation of dense, clustered 4-1BB signaling complexes at the point of contact between a $\mathrm{T}$ cell and a TAAdisplaying surface. The need for $4-1 \mathrm{BB}$ crosslinking beyond trimerization (i.e., hyper-crosslinking) has previously been reported as necessary for inducing strong $4-1 \mathrm{BB}$ signaling ${ }^{20}$.

Besides the potent tumor-specific costimulation, the $1 \mathrm{D} 88^{\mathrm{N}} /$ $\mathrm{C}_{\mathrm{EGal}}$ trimerbody exhibit improved serum stability as well as efficient and rapid localization to EGFR-positive tumors. The $1 \mathrm{D} 8^{\mathrm{N} / \mathrm{C}} \mathrm{EGa}$ trimerbody may be able to maximize tumor-specific costimulation due to the combination of a higher total tumor uptake and substantially faster circulatory clearance, ultimately giving an improved $\mathrm{T} / \mathrm{N}$ ratio as compared to conventional IgG- based anti-EGFR and anti-4-1BB antibodies. The magnitude of the protective antitumor response provided by the EGFR-targeted 4-1BB-agonistic trimerbody is equivalent to that observed for two well-characterized anti-4-1BB mAbs, $1 \mathrm{D} 8$ and $3 \mathrm{H}^{33}$. We show that the administration of the $1 \mathrm{D} 8^{\mathrm{N} / \mathrm{C}} \mathrm{EGal}$ trimerbody can eradicate established CT26 hEGFR tumors. Furthermore, rechallenging of the mice that rejected the tumor upon treatment with EGFR-targeted 4-1BB-agonistic trimerbody with fresh CT26 $6^{\text {mock }}$ cells failed to allow tumor implantation, thus indicating that longlasting tumor-specific memory had been established. In this study, the $4-1 \mathrm{BB}$ agonists were administered intraperitoneally, using a treatment regimen that has been validated for IgG-based anti-4-1BB antibodies ${ }^{15}$. Despite its significantly shorter terminal half-life, the $1 \mathrm{D} 88^{\mathrm{N} / \mathrm{C}} \mathrm{EGa1}$ trimerbody showed similar efficacy to $1 \mathrm{D} 8$ and $3 \mathrm{H} 3 \mathrm{mAbs}$, indicating that its quicker clearance is compensated for by other factors, potentially improved tumor retention due to higher avidity, and more extensive tumor penetration due to its structure. As $1 \mathrm{D} 88^{\mathrm{N} / \mathrm{C}} \mathrm{EGal}$ did not induce toxicity even when circulating at high concentrations for a 3-week period, half-life extension strategies can be explored, such as inclusion of albumin fragments or albumin-binding moieties ${ }^{46}$. The mechanism of action of IgG-based 4-1BB-agonistic antibodies has been interpreted as a consequence of enhanced antitumor $\mathrm{CD}^{+} \mathrm{T}$ cell responses ${ }^{47}$, and as the percentage of infiltrating $\mathrm{CD}^{+} \mathrm{T}$ cells is similar in $3 \mathrm{H} 3 \mathrm{IgG}-$ and $1 \mathrm{D} 8^{\mathrm{N} /}$ CEGa1-treated mice, it is likely that both IgG-based anti-4-1BB antibodies and tumor-targeted 4-1BB agonist trimerbody act in a mechanistically equivalent manner.

Toxicity has been the major impediment for first-generation 4$1 \mathrm{BB}$-agonistic mAbs. In preclinical murine models, systemic administration of IgG-based anti-4-1BB antibodies resulted in nonspecific immune stimulation and other immune-related anomalies that affected the function of organs such as the liver, spleen, and bone marrow ${ }^{14,48}$. Similarly to these mouse studies, clinical trials using urelumab have been associated with adverse effects at higher doses, such as liver toxicity that resulted in two fatalities ${ }^{16}$. Here we show that treatment of naive immunocompetent mice with the IgG-based anti-4-1BB-agonistic antibody resulted in severe toxicity, as assessed by enlarged spleen and liver, severe inflammation and fibrosis in the liver, spleen and pancreas, and systemic inflammatory cytokine production. Treatment with an EGFR-targeted 4-1BB-agonistic trimerbody lacked these immune-related side effects, even after an escalated regimen doubling the number of injections. Our study suggests that these immunological abnormalities and organ toxicities are mainly dependent on $\mathrm{FcR}$ interactions.

In summary, bispecific trimerbodies have been effectively applied to the treatment of established tumors by tumor-targeted 4-1BB costimulation and comprise a novel technology platform for the future development of this and similar immunotherapeutic approaches, e.g., tumor-specific costimulation through CD40 or OX40, and combining PD-L1 blocking with costimulatory strategies. The EGFR-targeted 4-1BB agonist trimerbody described in this study was successfully implemented from its design, as it had the desired structure, function, and stability. In vivo, it did not show the toxicities that have been associated with IgG-based 4-1BB agonist and have notoriously held them back in clinical trials. Our results emphasize the need for future studies with non-canonical immunotherapeutic antibodies in order to realize the therapeutic potential of 4-1BB costimulation.

\section{Methods}

Mice. C57BL/6, BALB/c, Hsd:ICR (CD-1), and Hsd:athymic Nude-Foxn1nu female mice were purchased from Harlan Iberica. Animals were housed in controlled conditions of temperature $\left(21 \pm 1{ }^{\circ} \mathrm{C}\right)$, humidity $(50 \pm 5 \%)$, and $12 \mathrm{~h} \mathrm{light} /$ dark cycles. Manipulation was performed in laminar flow hood, when necessary, 
and sterilized water and food were available ad libitum. All animal procedures conformed to European Union Directive 86/609/EEC and Recommendation 2007/ 526/EC, enforced in Spanish law under RD 1201/2005. Animal protocols were approved by the respective Ethics Committee of Animal Experimentation of the participant institutions: Instituto Investigación Sanitaria Puerta de Hierro-Segovia de Arana (Hospital Universitario Puerta de Hierro Majadahonda, Madrid, Spain), Intituto de Investigaciones Biomédicas "Alberto Sols" (IIBm) (CSIC-UAM,

Madrid), and Laboratory Animal Applied Research Platform (Parc Científic, Barcelona, Spain). Procedures were additionally approved by the Animal Welfare Division of the Environmental Affairs Council of the Government of Madrid (66/ $14,430 / 15,264 / 16)$ and by the Ethics Committee of the Catalonian authorities (9912).

Cells and culture conditions. HEK293 (CRL-1573), NIH/3T3 (CRL-1658), and A431 (CRL-1555) cells were obtained from ATCC and were grown in complete Dulbecco's modified Eagle's medium (DMEM) at $37^{\circ} \mathrm{C}$. HEK293 cells expressing m4-1BB (HEK239m4-1BB) ${ }^{49}$ were cultured in complete DMEM+500 $\mu \mathrm{g} / \mathrm{ml}$ G418. $\mathrm{NIH} / 3 \mathrm{~T} 3$ cells expressing human EGFR (3T3 $\left.3^{\mathrm{hEGFR}}\right)$ were provided by Dr A. Villalobo (IIBm, Madrid) ${ }^{50}$. Mouse CT26 cells (CRL-2638) infected with p-BABEpuro-hEGFR ${ }^{51}$ expressing human EGFR (CT26 $6^{\text {hEGFR }}$ ) or infected with the empty vector retrovirus (CT26 $6^{\text {mock }}$ ) were provided by Dr M. Rescigno (European Institute of Oncology, Milan) ${ }^{37}$. The cell lines were routinely screened for mycoplasma contamination by PCR (Stratagene).

Construction of expression vectors. A synthetic gene encoding the $1 \mathrm{D} 8 \mathrm{scFv}$ was synthesized by Geneart AG and subcloned as ClaI/NotI into pCR3.1-L36$\mathrm{NC1}^{31}$ resulting in pCR3.1-1D8-TIE ${ }^{18}$. To obtain the plasmids pCR3.1-1D8-TIE ${ }^{0}$ and pCR3.1-1D8-TIE 5 , two synthetic genes encoding the 1D8 scFv gene fused directly or by a 5-mer flexible linker to the N-terminus of the mouse TIEXVIII domain were synthesized by Geneart AG and subcloned as PstI/XbaI into pCR3.1$1 \mathrm{D} 8$-TIE ${ }^{18}$. To generate the bispecific trimerbody-expressing vector, the Bam HI/ $\mathrm{XbaI}$ fragment, containing the EGal gene, from pCR3.1-EGal-TIE ${ }^{74}$ was ligated into pCR3.1-1D8-TIE ${ }^{18}$ to obtain pCR3.1-1D8 ${ }^{\text {N18 }}$-TIE- ${ }^{18}$ EGal-myc/His. In order to introduce a N-terminal FLAG-StrepII tag, the HindIII/NotI fragment from pCR3.1-FLAG-StrepII-1D8-TIE ${ }^{18}$-iRGD was ligated into pCR3.1-1D8 ${ }^{\mathrm{N} 18}$-TIE${ }^{\mathrm{C} 18} \mathrm{EGa1}-\mathrm{myc} / \mathrm{Hi}$ to obtain pCR3.1-FLAG-StrepII-1D8 ${ }^{\mathrm{N18} / \mathrm{C} 18} \mathrm{EGa1}-\mathrm{myc} / \mathrm{His}$. The C-terminal myc/His tag was removed by PCR with LEGA-1 and Stop-XbaI-Rev primers (Supplementary Table 6) to generate pCR3.1-FLAG-StrepII-1D8 ${ }^{\mathrm{N} 18 /}$

${ }^{\mathrm{C} 18} \mathrm{EGal}$. The sequences were verified with Fw-CMV and Rv-BGH (Supplementary Table 6).

\section{Expression and purification of recombinant antibodies. HEK293 cells were} transfected with the appropriated vectors and selected in complete DMEM $+500 \mu \mathrm{g} / \mathrm{ml}$ G418 to generate stable cell lines. Recombinant antibodies were purified from conditioned media with HisTrap HP columns or with the (Twin-) Strep-tag purification system (IBA Lifesciences). Endotoxin levels were $<0.25 \mathrm{EU} / \mathrm{ml}$ as determined by the LAL Endotoxin Kit (Pierce).

Western blotting. Samples were separated under reducing conditions on $10-20 \%$ Tris-glycine gels and transferred onto nitrocellulose membranes and probed with either anti-c-myc (9E10, cat\#ab206486, Abcam) or anti-FLAG (M2, cat\#F480, Sigma-Aldrich) mAbs $(1 \mu \mathrm{g} / \mathrm{ml})$, followed by incubation with DyLight800-goat anti-mouse (GAM) IgG (1:5000 dilution) (cat\#610-145-121, Rockland Immunochemicals). Visualization of protein bands was performed with the Odyssey ${ }^{\circledast}$ system (LI-COR Biosciences).

Enzyme-linked immunosorbent assay. Mouse 4-1BB:hFc chimera (m4-1BB; cat\#937-4B-050, R\&D Systems) and human EGFR:hFc chimera (hEGFR; cat\#ab155726, Abcam) were immobilized $(3 \mu \mathrm{g} / \mathrm{ml})$ on Maxisorp plates (NUNC Brand Products) overnight at $4{ }^{\circ} \mathrm{C}$. After washing and blocking, conditioned media or purified protein solution $(1 \mu \mathrm{g} / \mathrm{ml})$ were added and incubated for $1 \mathrm{~h}$ at room temperature. The wells were washed and anti-c-myc mAb or anti-FLAG mAb added $(1 \mu \mathrm{g} / \mathrm{ml})$. After washing, horseradish peroxidase (HRP)-GAM IgG (1:1000 dilution) (cat\#A5278, Sigma-Aldrich) or HRP-goat anti-rat (GAR) IgG (1:1000 dilution) (cat\#ab97057, Abcam) were added, and the plate was developed using Ophenylenediamine dihydrochloride (OPD). For competition ELISA, m4-1BB $(3 \mu \mathrm{g} / \mathrm{ml})$ was immobilized, and after blocking, m4-1BBL (cat\#754402, Biolegend) was added at $4.27 \mathrm{nM}$ for $1 \mathrm{~h}$. Purified antibody solution $(4.27 \mathrm{nM})$ was serially two-fold diluted, added to the wells, and incubated for $1 \mathrm{~h}$. After washing, antiFLAG mAb $(1 \mu \mathrm{g} / \mathrm{ml})$ was added for $1 \mathrm{~h}$. After washing, HRP-GAM IgG (1:1000 dilution) was added and developed.

Flow cytometry. The cells were incubated for $1 \mathrm{~h}$ with purified antibodies $(6.67$ $\mathrm{nM}$ ), washed, incubated for $30 \mathrm{~min}$ with anti-His (BMG-His-1, cat\#11922416001, Roche Life Science) anti-c-myc or anti-FLAG mAbs $(1 \mu \mathrm{g} / \mathrm{ml})$, and were detected with a phycoerythrin (PE)-GAM IgG F(ab') antibody (1:200 dilution) (cat\#115116-072, Jackson Immuno Research). The 1D8 IgG (M. Jure-Kunkel, Bristol-Myers Squibb) and cetuximab (Merck KGaA) $(6.67 \mathrm{nM})$ were used as controls, using PE-
GAM IgG F $\left(\mathrm{ab}^{\prime}\right)_{2}$ (1:200 dilution) and PE-goat anti-human IgG $\mathrm{F}\left(\mathrm{ab}^{\prime}\right)_{2}(1: 50$ dilution) (cat\#109-116-097, Jackson Immuno Research), respectively. Samples were analyzed with a MACSQuant Analyzer 10 (Miltenyi Biotec GmbH). For competition studies, purified mouse CD8a ${ }^{+} \mathrm{T}$ cells were activated for $48 \mathrm{~h}$ with concanavalin-A ( $5 \mu \mathrm{g} / \mathrm{ml})$, blocked with human $\gamma$-globulin for $5 \mathrm{~min}$, incubated with $10 \mu \mathrm{g} / \mathrm{ml} 1 \mathrm{D} 8 \mathrm{IgG}$ for $20 \mathrm{~min}$ on ice, and washed with PBS thereafter, while the other samples were left untreated. Then cells were incubated with $2 \mu \mathrm{g} / \mathrm{ml}$ of $1 \mathrm{D} 8 \mathrm{IgG}, 1 \mathrm{D} 8^{\mathrm{N} 18}, 1 \mathrm{D} 8^{\mathrm{N} 5}$, or rat $\mathrm{IgG}_{2 \mathrm{a}}$ for $20 \mathrm{~min}$ on ice and washed. Next, cells that were incubated with $1 \mathrm{D} 8^{\mathrm{N} 18}$ or $1 \mathrm{D} 8^{\mathrm{N} 5}$ and one untreated control sample was incubated with rabbit anti-c-myc mAb (1:200 dilution) (A-14; cat\#sc789, Santa Cruz Biotechnology). Finally, cells were incubated with either Alexa 647-GAR IgG or donkey anti-rabbit IgG (1:100 dilution) (cat\#A-21247 and A-31573, Molecular Probes) together with fluorescein isothiocyanate (FITC)-anti-mouse CD8 mAb (1:500 dilution) (53-6.7; cat\#553030, BD Pharmigen) for $20 \mathrm{~min}$. Samples were analyzed with FACSCanto II and FACSort flow cytometers (BD Biosciences). To generate HEK293 cells homogeneously expressing high levels of 4-1BB (HEK293 ${ }^{\text {m-1BB }}$-S), HEK293 ${ }^{\text {m4-1BB }}$ cells were stained with PE-anti-mouse CD137 mAb (1:1000 dilution) (17B5; cat\#106105, Biolegend) and sorted using a FACSAria II (BD Biosciences).

Mass spectrometry. A $2 \mu \mathrm{l}$ protein sample was desalted using ZipTip ${ }^{\circledR}$ C4 microcolumns (Merck Millipore) and eluted with $0.5 \mu \mathrm{l}$ sinapinic acid $(10 \mathrm{mg} / \mathrm{ml}$ in [70:30] Acetonitrile: Trifluoroacetic acid 0.1\%) matrix onto a GroundSteel massive 384 target (Bruker Daltonics). An Autoflex III MALDI-TOF/TOF spectrometer (Bruker Daltonics) was used in linear mode with the following settings: 5000-40,000 Th window, linear positive mode, ion source $1: 20 \mathrm{kV}$, ion source 2 : $18.5 \mathrm{kV}$, lens: $9 \mathrm{kV}$, pulsed ion extraction of $120 \mathrm{~ns}$, high gating ion suppression up to $1000 \mathrm{Mr}$. Mass calibration was performed externally with protein 1 standard calibration mixture (Bruker Daltonics). Data acquisition, peak peaking, and subsequent spectra analysis was performed using the FlexControl 3.0 and FlexAnalysis 3.0 software (Bruker Daltonics).

Size exclusion chromatography with multi-angle light scattering. Static light scattering experiments were performed at room temperature using a Superdex 200 Increase 10/300 GL column (GE Healthcare) attached in-line to a DAWN-

HELEOS light scattering detector and an Optilab rEX differential refractive index detector (Wyatt Technology). The column has an exclusion volume of $8.6 \mathrm{ml}$, and no absorbance (no aggregated protein) was observed in any of the injections. The column was equilibrated with running buffer $(\mathrm{PBS}+150 \mathrm{Mm} \mathrm{NaCl})$ and the SECMALS system was calibrated with a sample of bovine serum albumin (BSA) at $1 \mathrm{~g} / \mathrm{l}$ in the same buffer. Then $100 \mu \mathrm{l}$ samples of the two antibodies $1 \mathrm{D} 8^{\mathrm{N} 18}$ and $1 \mathrm{D} 8^{\mathrm{N}} /$ ${ }^{C} \mathrm{EGal}$ at $1 \mathrm{~g} / \mathrm{l}$ in the running buffer were injected into the column at a flow rate of $0.5 \mathrm{ml} / \mathrm{min}$. Data acquisition and analysis were performed using the ASTRA software (Wyatt Technology). The reported molar mass corresponds to the center of the chromatography peaks. After separation of the monomeric species by SEC a second injection in the SEC-MALS system was done at $0.26 \mathrm{~g} / \mathrm{l}$. Based on numerous measurements on BSA samples at $1 \mathrm{~g} / \mathrm{l}$ under the same or similar conditions, we estimate that the experimental error in the molar mass is around $5 \%$.

Circular dichroism. Circular dichroism measurements were performed with a Jasco J-810 spectropolarimeter (JASCO). The spectra were recorded on protein samples at $0.2 \mathrm{~g} / \mathrm{l}$ in PBS using $0.2 \mathrm{~cm}$ path length quartz cuvettes at $25^{\circ} \mathrm{C}$. Thermal denaturation curves from 10 to $95^{\circ} \mathrm{C}$ were recorded on the same protein samples and cuvette by increasing temperature at a rate of $1{ }^{\circ} \mathrm{C} / \mathrm{min}$ and measuring the change in ellipticity at $218 \mathrm{~nm}$.

Small-angle X-ray scattering. SAXS experiments were performed the beamline B21 of the Diamond Light Source (Didcot, UK). The proteins were concentrated and prepared at $4{ }^{\circ} \mathrm{C}$ prior data collection. Samples of $40 \mu \mathrm{l}$ of $1 \mathrm{D} 8^{\mathrm{N} 18}$ and $1 \mathrm{D} 8^{\mathrm{N}}$ $\mathrm{C}_{\mathrm{EGal}}$ at concentrations of 3 and $6 \mathrm{mg} / \mathrm{ml}$ were delivered at $4{ }^{\circ} \mathrm{C}$ via an in-line Agilent $1200 \mathrm{HPLC}$ system in a Shodex $\mathrm{Kw}-403$ column, using a running buffer composed by $50 \mathrm{mM}$ Tris $\mathrm{pH} 7.5+150 \mathrm{mM} \mathrm{NaCl}$. The continuously eluting samples were exposed for $300 \mathrm{~s}$ in $10 \mathrm{~s}$ acquisition blocks using an X-ray wavelength of $1 \AA$ and a sample to detect (Pilatus $2 \mathrm{M}$ ) distance of $3.9 \mathrm{~m}$. The data covered a momentum transfer range of $0.032<q<3.695 \AA^{-1}$. The frames recorded immediately before elution of the sample were subtracted from the protein scattering profiles. The Scatter software package (www.bioisis.net) was used to analyze data, buffer-subtraction, scaling, merging, and checking possible radiation damage of the samples. The data set corresponding to $1 \mathrm{D} 8^{\mathrm{N} 18}$ at $3 \mathrm{mg} / \mathrm{ml}$ could not be further analyzed due to aggregation. The $R_{\mathrm{g}}$ values were calculated with the Guinier approximation assuming that at very small angles $q<1.3 / R_{\mathrm{g}}$. The maximum particle distribution, $D_{\max }$, and the distance distribution were calculated from the scattering pattern with GNOM, and shape estimation was carried out with DAMMIF/DAMMIN, and all these programs are included in the ATSAS package $^{52}$. Interactively generated PDB-based models were made for the two antibodies based in templates obtained with the program RaptorX. Real-space scattering profiles of the models were computed with the program FoXS. 
Kinetic measurements using BLI. The interactions between immobilized m4-1BB and $1 \mathrm{D} 8 \mathrm{IgG}, 1 \mathrm{D} 8^{\mathrm{N} 18}, 1 \mathrm{D} 8^{\mathrm{N} 5}$, and $1 \mathrm{D} 8^{\mathrm{N} 0}$ were investigated on an Octet

RED96 system (Fortebio). Mouse 4-1BB was immobilized onto AR2G biosensors (Fortebio) using $10 \mu \mathrm{g} / \mathrm{ml}$ of $\mathrm{m} 4-1 \mathrm{BB}$ in $10 \mathrm{mM}$ acetate buffer at $\mathrm{pH}$ 6, over $20 \mathrm{~min}$, to a signal of $1.8 \pm 0.4 \mathrm{~nm}$. The kinetics experiment for each antibody used 4 unregenerated m4-1BB-coated biosensors, 2 of which were associated with $4 \mathrm{nM}$ of antibody in kinetics buffer (PBS+0.1\% BSA $+0.05 \%$ Tween 20), and 2 with $2 \mathrm{nM}$. Association was run for $1 \mathrm{~h}$, followed by $3 \mathrm{~h}$ of dissociation in analyte-free kinetics buffer. The acquired sensorgrams were globally fit to a 1:1 model using the Octet Data analysis software. Kinetics experiments were performed at $37^{\circ} \mathrm{C}$ while shaken at $1000 \mathrm{rpm}$. The avidity of the interaction between immobilized hEGFR and analyte $1 \mathrm{D} 88^{\mathrm{N} / \mathrm{C}} \mathrm{EGa1}$ was investigated similarly. The hEGFR was immobilized onto AR2G biosensors using $3 \mu \mathrm{g} / \mathrm{ml}$ of hEGFR in $10 \mathrm{mM}$ acetate buffer at $\mathrm{pH} 5$. Association and dissociation were both measured for $2 \mathrm{~h}$. To demonstrate the ability of $1 \mathrm{D} 8^{\mathrm{N} / \mathrm{C} E G a 1}$ to bind both of its antigens in tandem, m4-1BB was immobilized onto AR2G biosensors, and $4 \mathrm{nM}$ of $1 \mathrm{D} 8^{\mathrm{N} / \mathrm{C}_{\mathrm{EGal}}}$ or $1 \mathrm{D} 8^{\mathrm{N} 18}$ were allowed to associate with 2 biosensors each for $1 \mathrm{~h}$. The biosensors were briefly moved into kinetics buffer for $10 \mathrm{~min}$, after which 1 biosensor loaded with each antibody was moved into $10 \mathrm{nM}$ hEGFR for $1 \mathrm{~h}$ while the other biosensor remained in kinetics buffer. Finally, all biosensors were moved into kinetics buffer for $1 \mathrm{~h}$.

Serum stability. Purified antibodies were incubated in human serum at $37^{\circ} \mathrm{C}$, for at least 7 days. The binding activity of the sample at $0 \mathrm{~h}$ was set as $100 \%$ in order to calculate the time corresponding to percentage of decay in binding activity.

T cell costimulation assays. Goat anti-hamster IgG (cat\#127-005-160, Jackson ImmunoReserach) was pre-coated overnight at $4{ }^{\circ} \mathrm{C}$ in 96 -well plates $(5 \mu \mathrm{g} / \mathrm{ml})$, and after blocking, anti-CD3 mAb (145-2C11; cat\# MO3PU(V100), Immunostep) $(1 \mu \mathrm{g} / \mathrm{ml})$ was added and incubated at $37^{\circ} \mathrm{C}$ for $1 \mathrm{~h}$. Mouse CD8a ${ }^{+} \mathrm{T}$ cells were purified from the spleens of C57BL/6 mice using the EasySep ${ }^{\text {pt }}$ Mouse CD8a ${ }^{+} \mathrm{T}$ Cell Isolation Kit (Stem Cell Technologies). Then purified mouse CD8a ${ }^{+} \mathrm{T}$ cells $(2.5 \times$ $10^{5} /$ well $)$ in complete RPMI $+50 \mu \mathrm{M} 2$-mercaptoethanol, and purified antibodies at $6.67 \mathrm{nM}$ were added. As a control, purified mouse $\mathrm{CD} 8 \mathrm{a}^{+} \mathrm{T}$ cells were cultured alone with the immobilized anti-CD3 $\mathrm{mAb}(1 \mu \mathrm{g} / \mathrm{ml})$. After $48 \mathrm{~h}$, cell proliferation was assessed with the CellTiter-Glo luminescent assay (Promega) using a Tecan Infinite F200 plate-reading luminometer, and supernatants were collected and assayed for IFN- $\gamma$ secretion by ELISA (Diaclone). For viability assays, cells were collected after $72 \mathrm{~h}$, incubated with FITC-Annexin V (Immunostep) and 7-AAD (BD Biosciences), and analyzed with a MACSQuant Analyzer 10. Results are expressed as a mean $\pm \mathrm{SD}$ from one of at least three separate experiments.

Antigen-specific $\mathbf{T}$ cell costimulation assays. For studies with purified hEGFR, 96-well plates were pre-coated with goat anti-hamster IgG $(5 \mu \mathrm{g} / \mathrm{ml})$ and hEGFR $(5 \mu \mathrm{g} /$ well $)$. After blocking, anti-CD3 mAb $(1 \mu \mathrm{g} / \mathrm{ml})$ was added and incubated for $1 \mathrm{~h}$ at $37^{\circ} \mathrm{C}$, before adding mouse CD8 $\mathrm{a}^{+} \mathrm{T}$ cells and the purified antibodies $(6.67 \mathrm{nM})$. For studies with cells, NIH/3T3 or $3 \mathrm{~T} 3^{\mathrm{hEGFR}}$ target cells were seeded overnight. Next day, target cells were pre-incubated for $30 \mathrm{~min}$ on ice with purified antibodies $(6.67 \mathrm{nM})$. Mouse $\mathrm{CD} 8 \mathrm{a}^{+} \mathrm{T}$ cells were activated with biotin-anti-CD3 $\mathrm{mAb}(145-2 \mathrm{C} 11$, cat\#100303, Biolegend) $(100 \mathrm{ng} / \mathrm{ml})$ cross-linked with streptavidin (1:5 molar ratio) and added at 10:1 effector/target ratio. As a control, mouse $\mathrm{CD} 8 \mathrm{a}^{+} \mathrm{T}$ cells were cultured alone with plastic immobilized anti-CD3 mAb $(1 \mu \mathrm{g} / \mathrm{ml})$. Cell proliferation and IFN- $\gamma$ secretion were measured after $48 \mathrm{~h}$, and cell viability after $72 \mathrm{~h}$. Results are expressed as a mean \pm SD from one of at least three separate experiments.

Inhibition of EGFR-mediated cell proliferation and signaling. A431 cells were seeded in complete DMEM in 96-well plates. After $24 \mathrm{~h}$, medium was replaced by DMEM $+1 \%$ fetal calf serum (FCS) containing equimolar concentrations $(0.19-50 \mathrm{nM})$ of cetuximab, rituximab (Hoffmann-La Roche Ltd.), $1 \mathrm{D} 8^{\mathrm{N} / \mathrm{C}} \mathrm{EGa1}$, or 1D8 IgG and incubated for $72 \mathrm{~h}$. Viability was assessed using the CellTiter-Glo luminescent assay. Experiments were performed in triplicates. For EGFR signaling studies, A431cells were starved overnight in DMEM $+1 \%$ FCS and then incubated for $4 \mathrm{~h}$ in serum-free DMEM in the presence of $0.1 \mu \mathrm{M}$ cetuximab, rituximab, $1 \mathrm{D} 8^{\mathrm{N} / \mathrm{C}} \mathrm{EGa1}$, or 1D8 IgG, followed by incubation with $25 \mathrm{ng} / \mathrm{ml}$ of human EGF (MiltenyiBiotec $\mathrm{GmbH}$ ) for $5 \mathrm{~min}$. After stimulation, cells were lysed in Laemmlilysis buffer, separated under reducing conditions on $4-12 \%$ Tris-glycine gels, transferred to nitrocellulose membrane, and incubated with the rabbit anti-human phosphor-EGFR (Tyr1068) mAb (1:1000 dilution) (D7A5; cat\#3777, Cell Signaling Technology Inc.) followed by incubation with an IRDye800CW-donkey anti-rabbit antibody (1:5000 dilution) (cat\#925-32213, LI-COR Biosciences). Simultaneously, anti- $\beta$-actin mouse mAb (1:2000 dilution) (8226; cat\#ab8226, Abcam) was added as a loading control, followed by IRDye680RD-donkey anti-mouse IgG (1:5000 dilution) (cat\#925-68072, LI-COR Biosciences). Visualization and quantitative analysis of protein bands were carried out with the Odyssey system.

Antibody labeling. Purified $1 \mathrm{D} 8 \mathrm{IgG}, 1 \mathrm{D} 88^{\mathrm{N} 18}$, and 4-1BBL were labeled with the Mix-n-Stain CF488A Antibody Labeling Kit, and purified 3H3 IgG (cat\#BE0239, BioXCell) and $1 \mathrm{D} 88^{\mathrm{N} / \mathrm{C}} \mathrm{EGal}$ were labeled with NIR fluorochrome CF647 using the Mix-n-Stain CF647 Antibody Labeling Kit according to the manufacturer's recommendations (Biotium). Cetuximab was labeled with NIR fluorochrome $\mathrm{Cy}_{5}{ }^{\mathrm{TM}}$ Mono NHS Ester (GE Healthcare) according to the manufacturer's recommendations. The degree of labeling (DOL) was determined from the absorption spectrum of the labeled antibody; $1.5 / 1$ and $2.7 / 1$ dye/protein in the case of CF488A- and CF647-labeled proteins, respectively. Cetuximab has a DOL of 2.3/ 1 dye/protein.

Live cell receptor clustering imaging. HEK293 ${ }^{\mathrm{m} 4-1 \mathrm{BB}}-\mathrm{S}$ cells were plated onto $35-$ $\mathrm{mm}$ poly-L-lysine pre-coated dishes at a $50 \%$ confluence, and after overnight culture, the dishes were assembled in $35-\mathrm{mm}$ diameter chambers (Ibidi $\mathrm{GmbH}$ ) with $600 \mu \mathrm{l}$ of dichloromethane and set onto a Leica SP8 3X SMD microscope (Leica Microsystems) under $37^{\circ} \mathrm{C}$ and $5 \% \mathrm{CO}_{2}$ conditions. The excitation wavelength used was $488 \mathrm{~nm}$ from a white light laser (NKT Photonics A/S) with very low power 2-5\%, and the detection was from 500 to $550 \mathrm{~nm}$. CF488A-labeled 1D8 IgG, $1 \mathrm{D} 8^{\mathrm{N} 18}$, or $4-1 \mathrm{BBL}$ were extemporaneously added to the cells at a final concentration of $100 \mathrm{ng} / \mathrm{ml}$, and RICS was performed. Characterization of the microscope point spread function, i.e., the focal volume where the fluorescent dyes diffuse in and out, was done employing $2 \mu \mathrm{g} / \mathrm{ml}$ soluble purified EGFP

$(\text { Biovision })^{34}$. The series of images recorded for RICS were of $256 \times 256$ pixels, with a pixel size of $80 \mathrm{~nm}$, and employing 2- $\mu$ s dwell time. RICS analysis and diffusion coefficient quantification was done by employing the SIM FCS 4 software (G-SOFT Inc.). Every time trace from the time series was carefully observed to avoid possible artifacts due to dramatic photobleaching, which otherwise would affect the diffusion coefficient quantification. By these means, we avoided employing detrending algorithms that sometimes can bias the analysis. RICS analysis was performed using a moving average (background subtraction) of ten to discard possible artifacts arising from cellular motion and slow-moving particles passing through. The obtained two-dimensional autocorrelation map was fitted to get the diffusion surface map that was represented in three dimension. For the different region of interest (ROI) analyses within the same cell, the corresponding region was drawn employing a square region of $64 \times 64$ pixels. Selected regions were defined as where there was the presence or absence of receptor clustering. For statistical purposes, each condition was studied on minimum five different cells, and in each cell a minimum of three different ROIs were analyzed. Brightness and contrast of the fluorescence and differential interference contrast were optimized with the Image software. Diffusion values were represented in a whisker and box plot using OriginPro (OriginLab).

Pharmacokinetics study. Female CD-1 mice ( $n=24$ /group) received a single i.v. dose of $1 \mathrm{D} 8^{\mathrm{N} 18}$ or $1 \mathrm{D} 8^{\mathrm{N} / \mathrm{C}} \mathrm{EGal}(1 \mathrm{mg} / \mathrm{kg})$, and blood samples from 3 mice per group were collected at 5, 15, 30 min and 1, 3, 6, 24, and $48 \mathrm{~h}$. Female BALB/C mice were injected i.v. ( $n=24 /$ group) or i.p. ( $n=6 /$ group) with a single dose of $3 \mathrm{H} 3 \mathrm{IgG}$ or $1 \mathrm{D} 8{ }^{\mathrm{N} / \mathrm{C}} \mathrm{EGa} 1(1 \mathrm{mg} / \mathrm{kg})$. Serial blood samples were obtained at different time points from $30 \mathrm{~min}$ to $264 \mathrm{~h}$. Serum was obtained after centrifugation and stored at $-20{ }^{\circ} \mathrm{C}$. Sera were analyzed for antibody concentration by ELISA against immobilized m4-1BB $(3 \mu \mathrm{g} / \mathrm{ml})$. After washing and blocking, sera from different time points were added and incubated for $1 \mathrm{~h}$ at room temperature. The wells were washed and HRP-anti-c-myc $(1 \mu \mathrm{g} / \mathrm{ml})$ (cat\#ab1326, Abcam), HRPanti-FLAG mAb (1 $\mu \mathrm{g} / \mathrm{ml})(\mathrm{M} 2$; cat\#ab49763, Abcam), or HRP-GAR IgG (1:1000 dilution) were added. After washing, the plates were developed using OPD. Pharmacokinetic parameters were calculated using the Prism software (GraphPad Software).

Molecular imaging in tumor-bearing mice. A431 cells $\left(1 \times 10^{6}\right)$ were implanted s. c. into the dorsal space of 6-week-old female Hsd:athymic Nude-Foxn1nu mice. Tumor growth was monitored two times a week by measuring the diameter of the tumors with a calliper, and tumor volumes were calculated according to the formula: Volume $=(D \times d 2 / 2)$, where $D$ is the longest axis of the tumor and $d$ is the shortest of a prolate ellipse. When tumor volume reached about $0.180 \mathrm{~cm}^{3}$, mice were randomly allocated to different treatment groups $(n=3 /$ group $)$ and i.v. injected with PBS or NIR-labeled antibody solution $(1 \mathrm{mg} / \mathrm{ml})$ in PBS. Mice were imaged under anesthesia at $24 \mathrm{~h}$ under the IVIS Spectrum CT in vivo imaging system (Xenogen) at the indicated wavelengths and were analyzed using the Living Image 3.2 software (PerkinElmer). The images were analyzed by identifying 3 ROIs within the tumor and from surrounding regions (normal tissue). The $\mathrm{T} / \mathrm{N}$ ratio was calculated by dividing the mean values of the identified ROIs. Fluorescence intensity of all the images are reported as photons per second per centimeter squared per steradian $\left(\mathrm{p} / \mathrm{s} / \mathrm{cm}^{2} / \mathrm{sr}\right)$.

Therapeutic studies. CT26 hEGFR cells $\left(1.5 \times 10^{6}\right)$ were implanted s.c. into the dorsal space of 6 -week-old female BALB/c mice. Tumor growth was monitored by calliper measurements three times a week, and when tumors reached approximately $0.4 \mathrm{~cm}$ in diameter (usually from 7 to 10 days), mice were randomized to receive treatment ( $n=5$ or 6/group). Measurements were conducted in a random order by the investigator who was blinded to the treatment assignment. Mice were treated every other day with three i.p. injections of PBS, anti-4-1BB antibodies, or control antibodies $(4 \mathrm{mg} / \mathrm{Kg})$. Mice were euthanized when tumor size reached a diameter of $1.5 \mathrm{~cm}$ any dimension, when tumors ulcerated, or at any sign of mouse distress. To study the long-lasting systemic immune-mediated response, surviving 
mice $(n=5)$ were re-challenged with CT26 $6^{\text {mock }}$ cells $\left(1.5 \times 10^{6}\right)$ s.c. in the contralateral left flank 50 days following treatment with $3 \mathrm{H} 3 \mathrm{IgG}$ or $1 \mathrm{D} 8{ }^{\mathrm{N} / \mathrm{C}_{\mathrm{EGal}}}$. Cured and naive mice were followed for an additional 190 days after reinoculation.

Immunohistochemistry. CT26 $6^{\text {hEGFR }}$ tumors from different treatment groups were collected after 13 days of implantation and fixed in $10 \%$ neutral buffered formalin (Sigma-Aldrich) for $48 \mathrm{~h}$. Then, after extensive washing in PBS, tissues were embedded in paraffin, cut at $3 \mu \mathrm{m}$, mounted in Superfrost ${ }^{\oplus}$ plus slides, and dried overnight. Slides were deparaffined in xylene and re-hydrated through a series of graded ethanol washes, ending in a final rinse in pure water. Slides were incubated with a rat monoclonal anti-CD8a (1:200 dilution) (OTO94A; Monoclonal Antibodies Core Unit CNIO) followed by a rabbit anti-rat secondary antibody (cat\#ab6703, Abcam) and a visualization system (Novolink Polymer anti-Rabbit, Leica) conjugated with HRP. Nuclei were counterstained with Harris' hematoxylin. Positive control sections known to be primary antibody positive were included for each staining run. Whole digital slides were acquired with a slide scanner (AxioScan Z1, Zeiss), and total versus positive cells were automatically quantified (AxioVision 4.6 software package, Zeiss).

Toxicity studies. Three-month-old female C57BL/6 received a weekly i.p. dose of $3 \mathrm{H} 3 \mathrm{IgG}$ or $1 \mathrm{D} 8{ }^{\mathrm{N} / \mathrm{C}} \mathrm{EGal}(6 \mathrm{mg} / \mathrm{kg})$ for 3 weeks. Mice were anesthetized and bled on days $0,7,14$, and 21 . To obtain mouse serum, blood was incubated in BD microtainer SST tubes (BD Biosciences), followed by centrifugation. Serum was stored at $-20{ }^{\circ} \mathrm{C}$ until use. One week after the last dose of antibodies, mice were euthanized and the liver, spleens, lungs, and pancreas were surgically removed, weighted, and fixed in 10\% paraformaldehyde for $48 \mathrm{~h}$. Then fixed tissues were washed and embedded in paraffin. Tissue sections $(5 \mu \mathrm{m})$ were stained with hematoxylin and eosin, Sirius red, or Masson's trichrome (Sigma-Aldrich) for collagen staining. Lymphocyte infiltration in the liver was quantified using the Image software. A similar study was performed in 2-month-old female BALB/c mice, but in this case the $1 \mathrm{D}^{\mathrm{N} / \mathrm{C}} \mathrm{EGal}$ was injected i.p. every $3 / 4$ days $(6 \mathrm{mg} / \mathrm{kg})$ for 3 weeks. The $3 \mathrm{H} 3 \mathrm{IgG}$ was administered with the same regimen: a weekly i.p. injection $(6 \mathrm{mg} / \mathrm{kg})$ for 3 weeks.

Luminex assay. Blood was collected from the treated mice on the indicated days, and the levels of inflammatory cytokines (IFN- $\gamma$, IL-6, TNF- $\alpha$ ) in serum samples were determined using a Luminex Milliplex Magnetic Bead Kit (Merck Millipore).

Statistical analysis. Statistical analysis was performed using the GraphPad Prism Software version 5.0. All the in vitro experiments were done in triplicates and values are presented as mean $\pm \mathrm{SD}$ from one of at least three separate experiments. Significant differences ( $P$ value) were discriminated by applying a two-tailed, unpaired Student's $t$ test assuming a normal distribution with ${ }^{\star} P \leq 0.05,{ }^{*} P \leq 0.01$, ${ }_{* * *} P \leq 0.001$. To assess differences in tumor growth, tumor diameter for individual mice in each treatment group are presented. Survival curves for the different treatment groups were created using the Kaplan-Meier method, and two or more survival curves were analyzed using log-rank (Mantel-Cox) test. For the other in vivo studies, data were presented using a scatter plot as mean $\pm \mathrm{SD}$, and $P$ values were determined by unpaired Student's $t$ test to assess the differences between treatment groups.

\section{Data availability}

The authors declare that the data supporting this study are available within the paper and its Supplementary Information File. All other data are available from the authors upon reasonable request.

Received: 5 June 2018 Accepted: 17 October 2018

Published online: 15 November 2018

\section{References}

1. Melero, I. et al. Evolving synergistic combinations of targeted immunotherapies to combat cancer. Nat. Rev. Cancer 15, 457-472 (2015).

2. Jensen, S. M. et al. Signaling through OX40 enhances antitumor immunity. Semin. Oncol. 37, 524-532 (2010).

3. Vinay, D. S. \& Kwon, B. S. Immunotherapy of cancer with 4-1BB. Mol. Cancer Ther. 11, 1062-1070 (2012).

4. Khong, A., Nelson, D. J., Nowak, A. K., Lake, R. A. \& Robinson, B. W. The use of agonistic anti-CD40 therapy in treatments for cancer. Int. Rev. Immunol. 31, 246-266 (2012).

5. Suntharalingam, G. et al. Cytokine storm in a phase 1 trial of the anti-CD28 monoclonal antibody TGN1412. N. Engl. J. Med. 355, 1018-1028 (2006).

6. Pollok, K. E. et al. 4-1BB T-cell antigen binds to mature B cells and macrophages, and costimulates anti-mu-primed splenic B cells. Eur. J. Immunol. 24, 367-374 (1994).
7. Kroon, H. M. et al. 4-1BB costimulation of effector T cells for adoptive immunotherapy of cancer: involvement of Bcl gene family members. $J$. Immunother. 30, 406-416 (2007).

8. Sabbagh, L., Pulle, G., Liu, Y., Tsitsikov, E. N. \& Watts, T. H. ERK-dependent Bim modulation downstream of the 4-1BB-TRAF1 signaling axis is a critical mediator of CD8 T cell survival in vivo. J. Immunol. 180, 8093-8101 (2008).

9. Wilcox, R. A., Tamada, K., Strome, S. E. \& Chen, L. Signaling through NK cell associated CD137 promotes both helper function for CD8+ cytolytic T cells and responsiveness to IL-2 but not cytolytic activity. J. Immunol. 169, 4230-4236 (2002).

10. Kohrt, H. E. et al. CD137 stimulation enhances the antilymphoma activity of anti-CD20 antibodies. Blood 117, 2423-2432 (2011).

11. Kohrt, H. E. et al. Stimulation of natural killer cells with a CD137-specific antibody enhances trastuzumab efficacy in xenotransplant models of breast cancer. J. Clin. Invest. 122, 1066-1075 (2012).

12. Melero, I. et al. Monoclonal antibodies against the 4-1BB T-cell activation molecule eradicate established tumors. Nat. Med. 3, 682-685 (1997).

13. Alfaro, C. et al. Functional expression of CD137 (4-1BB) on T helper follicular cells. Oncoimmunology 4, e1054597 (2015).

14. Niu, L. et al. Cytokine-mediated disruption of lymphocyte trafficking, hemopoiesis, and induction of lymphopenia, anemia, and thrombocytopenia in anti-CD137-treated mice. J. Immunol. 178, 4194-4213 (2007).

15. Dubrot, J. et al. Treatment with anti-CD137 mAbs causes intense accumulations of liver $\mathrm{T}$ cells without selective antitumor immunotherapeutic effects in this organ. Cancer Immunol. Immunother. 59, 1223-1233 (2010).

16. Melero, I., Hirschhorn-Cymerman, D., Morales-Kastresana, A., Sanmamed, M. F. \& Wolchok, J. D. Agonist antibodies to TNFR molecules that costimulate T and NK cells. Clin. Cancer Res. 19, 1044-1053 (2013).

17. Bartkowiak, T. \& Curran, M. A. 4-1BB agonists: multi-potent potentiators of tumor immunity. Front. Oncol. 5, 117 (2015).

18. Massarelli, E. Clinical safety and efficacy assessment of the CD137 agonist urelumab alone and in combination with nivolumab in patients with hematologic and solid tumor malignancies. In Proc. 31st Annual Meeting and Associated Programs of the Society for Immunotherapy of Cancer. Poster number 239 (2016).

19. Segal, N. H. et al. Results from an integrated safety analysis of urelumab, an agonist anti-CD137 monoclonal antibody. Clin. Cancer Res. 23, 1929-1936 (2017).

20. Chester, C., Sanmamed, M. F., Wang, J. \& Melero, I. Immunotherapy targeting 4-1BB: mechanistic rationale, clinical results, and future strategies. Blood 131, 49-57 (2018).

21. Rabu, C. et al. Production of recombinant human trimeric CD137L (4-1BBL). Cross-linking is essential to its T cell co-stimulation activity. J. Biol. Chem. 280, 41472-41481 (2005).

22. Wyzgol, A. et al. Trimer stabilization, oligomerization, and antibody-mediated cell surface immobilization improve the activity of soluble trimers of CD27L, CD40L, 41BBL, and glucocorticoid-induced TNF receptor ligand. J. Immunol. 183, 1851-1861 (2009).

23. Ye, Z. et al. Gene therapy for cancer using single-chain Fv fragments specific for 4-1BB. Nat. Med. 8, 343-348 (2002).

24. Yang, Y. et al. Tumor cells expressing anti-CD137 scFv induce a tumordestructive environment. Cancer Res. 67, 2339-2344 (2007).

25. Fellermeier, S. et al. Advancing targeted co-stimulation with antibody-fusion proteins by introducing TNF superfamily members in a single-chain format. Oncoimmunology 5, e1238540 (2016).

26. Pastor, F., Kolonias, D., McNamara, J. O. \& Gilboa, E. Targeting 4-1BB costimulation to disseminated tumor lesions with bi-specific oligonucleotide aptamers. Mol. Ther. 19, 1878-1886 (2011).

27. Schrand, B. et al. Targeting 4-1BB costimulation to the tumor stroma with bispecific aptamer conjugates enhances the therapeutic index of tumor immunotherapy. Cancer Immunol. Res. 2, 867-877 (2014).

28. Zhang, Y., Li, N., Suh, H. \& Irvine, D. J. Nanoparticle anchoring targets immune agonists to tumors enabling anti-cancer immunity without systemic toxicity. Nat. Commun. 9, 6 (2018).

29. Cuesta, A. M. et al. In vivo tumor targeting and imaging with engineered trivalent antibody fragments containing collagen-derived sequences. PLoS ONE 4, e5381 (2009).

30. Sanchez-Martin, D., Cuesta, A. M., Fogal, V., Ruoslahti, E. \& varez-Vallina, L. The multicompartmental p32/gClqR as a new target for antibody-based tumor targeting strategies. J. Biol. Chem. 286, 5197-5203 (2011).

31. Blanco-Toribio, A. et al. Generation and characterization of monospecific and bispecific hexavalent trimerbodies. mAbs 5, 70-79 (2013).

32. Schmitz, K. R., Bagchi, A., Roovers, R. C., van Bergen en Henegouwen, P. M. \& Ferguson, K. M. Structural evaluation of EGFR inhibition mechanisms for nanobodies/VHH domains. Structure 21, 1214-1224 (2013).

33. Shuford, W. W. et al. 4-1BB costimulatory signals preferentially induce CD8+ $\mathrm{T}$ cell proliferation and lead to the amplification in vivo of cytotoxic $\mathrm{T}$ cell responses. J. Exp. Med. 186, 47-55 (1997). 
34. Garcia, E., de Bernardino, l. A. \& Serna, J. Dissecting single-cell molecular spatiotemporal mobility and clustering at focal adhesions in polarised cells by fluorescence fluctuation spectroscopy methods. Methods 140-141, 85-96 (2018).

35. Boudko, S. P. et al. Crystal structure of human collagen XVIII trimerization domain: A novel collagen trimerization Fold. J. Mol. Biol. 392, 787-802 (2009).

36. Harwood, S. L. et al. ATTACK, a novel bispecific T cell-recruiting antibody with trivalent EGFR binding and monovalent CD3 binding for cancer immunotherapy. Oncoimmunology 7, e1377874 (2017).

37. Pozzi, C. et al. The EGFR-specific antibody cetuximab combined with chemotherapy triggers immunogenic cell death. Nat. Med. 22, 624-631 (2016).

38. Mittler, R. S., Bailey, T. S., Klussman, K., Trailsmith, M. D. \& Hoffmann, M. K. Anti-4-1BB monoclonal antibodies abrogate T cell-dependent humoral immune responses in vivo through the induction of helper T cell anergy. J. Exp. Med. 190, 1535-1540 (1999).

39. Narazaki, H., Zhu, Y., Luo, L., Zhu, G. \& Chen, L. CD137 agonist antibody prevents cancer recurrence: contribution of CD137 on both hematopoietic and nonhematopoietic cells. Blood 115, 1941-1948 (2010).

40. Quetglas, J. I. et al. Immunotherapeutic synergy between anti-CD137 mAb and intratumoral administration of a cytopathic Semliki Forest virus encoding IL-12. Mol. Ther. 20, 1664-1675 (2012).

41. Kohrt, H. E. et al. Targeting CD137 enhances the efficacy of cetuximab. J. Clin. Invest. 124, 2668-2682 (2014).

42. Álvarez-Cienfuegos, A. et al. Intramolecular trimerization, a novel strategy for making multispecific antibodies with controlled orientation of the antigen binding domains. Sci. Rep. 6, 28643 (2016).

43. Cuesta, A. M. et al. Improved stability of multivalent antibodies containing the human collagen XV trimerization domain. mAbs 4, 226-232(2012).

44. Kortt, A. A., Dolezal, O., Power, B. E. \& Hudson, P. J. Dimeric and trimeric antibodies: high avidity scFvs for cancer targeting. Biomol. Eng. 18, 95-108 (2001).

45. Long, A. H. et al. 4-1BB costimulation ameliorates $\mathrm{T}$ cell exhaustion induced by tonic signaling of chimeric antigen receptors. Nat. Med. 21, 581-590 (2015).

46. Kontermann, R. E. Half-life extended biotherapeutics. Expert Opin. Biol. Ther. 16, 903-915 (2016).

47. Palazon, A. et al. Agonist anti-CD137 mAb act on tumor endothelial cells to enhance recruitment of activated T lymphocytes. Cancer Res. 71, 801-811 (2011).

48. Lee, S. W., Salek-Ardakani, S., Mittler, R. S. \& Croft, M. Hypercostimulation through 4-1BB distorts homeostasis of immune cells. J. Immunol. 182, 6753-6762 (2009).

49. Martinez-Forero, I. et al. T cell costimulation with anti-CD137 monoclonal antibodies is mediated by K63-polyubiquitin-dependent signals from endosomes. J. Immunol. 190, 6694-6706 (2013).

50. Estrada, C. et al. Nitric oxide reversibly inhibits the epidermal growth factor receptor tyrosine kinase. Biochem. J. 326(Pt 2), 369-376 (1997)

51. Sigismund, S. et al. Threshold-controlled ubiquitination of the EGFR directs receptor fate. EMBO J. 32, 2140-2157 (2013).

52. Petoukhov, M. V. et al. New developments in the ATSAS program package for small-angle scattering data analysis. J. Appl. Crystallogr 45, 342-350(2012).

\section{Acknowledgments}

We thank M. Jure-Kunkel, M. Rescigno and A. Villalobo for reagents, M.G. Gonzalez Bueno and B. Acosta (IIBm) for technical support, and the staff of beamline B21at Diamond Light Source (Didcot, UK) for their excellent technical assistance. This study was supported by grants from the European Union [IACT Project (602262), iNEXT Project (1676) and a Marie Curie Career Integration Grant (PCIG13-GA-2013-618914)], the Ministerio de Economía y Competitividad (CTQ2017-83810-R, RTC-2016-5118-1, SAF2017-83267-C2-1-R, SAF2017-89437-P, and PTQ-16-08340), the Fondo de Investigación Sanitaria/Instituto de Salud Carlos III (PI16/00357 and PI16/00895), the UK Research and Innovation (18130023), and the Danish Council for Independent Research (DFF-6110-0053). The CIC bioGUNE is a Severo Ochoa Center of Excellence (Ministerio de Economia y Competitividad award SEV-2016-0644). This study was also funded by FEDER.

\section{Author contributions}

L.A.-V. and M.C. conceived and supervised the study. M.C., S.L.H., I.G.M., R.N., M.Z., G. P.-C., A.E.-L., N.M., A.T.-G., A.M.C., K.M., E.C., N.N.-P., M.A.A., S.L., and J.M.-T. designed and performed most of the experiments. M.C., S.L.H., I.G.M., J.M.-T., I.M., F.J. B., J.B.S., J.M.Z., L.S., and L.A.-V. analyzed and discussed the data and wrote the manuscript. All authors edited the manuscript.

\section{Additional information}

Supplementary Information accompanies this paper at https://doi.org/10.1038/s41467 018-07195-w.

Competing interests: M.C., M.Z., and A.E.-L. are all employees of Leadartis. L.A.-V. and L.S. are co-founders of Leadartis. The remaining authors declare no competing interests.

Reprints and permission information is available online at http://npg.nature.com/ reprintsandpermissions/

Publisher's note: Springer Nature remains neutral with regard to jurisdictional claims in published maps and institutional affiliations.

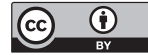

Open Access This article is licensed under a Creative Commons Attribution 4.0 International License, which permits use, sharing, adaptation, distribution and reproduction in any medium or format, as long as you give appropriate credit to the original author(s) and the source, provide a link to the Creative Commons license, and indicate if changes were made. The images or other third party material in this article are included in the article's Creative Commons license, unless indicated otherwise in a credit line to the material. If material is not included in the article's Creative Commons license and your intended use is not permitted by statutory regulation or exceeds the permitted use, you will need to obtain permission directly from the copyright holder. To view a copy of this license, visit http://creativecommons.org/ licenses/by/4.0/.

(C) The Author(s) 2018 